AperTO - Archivio Istituzionale Open Access dell'Università di Torino

\title{
Plastid DNA fingerprinting of the rare Fritillaria moggridgei (Liliaceae) reveals population differentiation and genetic isolation within the Fritillaria tubiformis complex
}

\section{This is the author's manuscript}

Original Citation:

\section{Availability:}

This version is available http://hdl.handle.net/2318/133411

since 2016-01-24T11:46:50Z

Published version:

DOI:10.11646/phytotaxa.91.1.1

Terms of use:

Open Access

Anyone can freely access the full text of works made available as "Open Access". Works made available under a Creative Commons license can be used according to the terms and conditions of said license. Use of all other works requires consent of the right holder (author or publisher) if not exempted from copyright protection by the applicable law. 


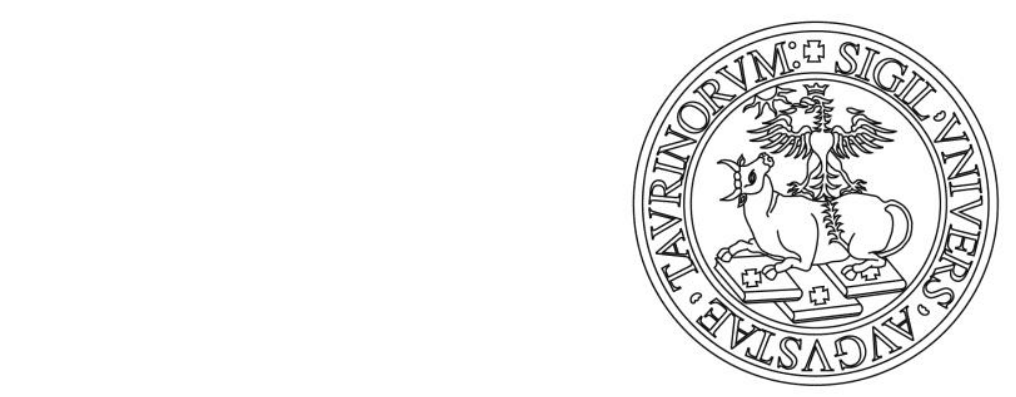

\section{UNIVERSITÀ DEGLI STUDI DI TORINO}

This is an author version of the contribution published on:

Questa è la versione dell'autore dell'opera:

Plastid DNA fingerprinting of the rare Fritillaria moggridgei (Liliaceae) reveals population differentiation and genetic isolation within the Fritillaria tubiformis complex.

Phytotaxa, published online 2 April 2013, http://dx.doi.org/10.11646/phytotaxa.91.1.1

The definitive version is available at:

La versione definitiva è disponibile alla URL:

http://biotaxa.org/Phytotaxa/article/view/phytotaxa.91.1.1 


\title{
Plastid DNA fingerprinting of the rare Fritillaria moggridgei (Liliaceae) reveals population differentiation and genetic isolation within the Fritillaria tubiformis complex.
}

\author{
MARCO MUCCIARELLI ${ }^{1} \&$ MICHAEL F. FAY $^{2}$ \\ ${ }^{1}$ Department of Life Sciences and Systems Biology, Torino, I-10125 Italy, e-mail: \\ marco.mucciarelli@unito.it \\ ${ }^{2}$ Jodrell Laboratory, Royal Botanic Gardens, Kew, Richmond, Surrey TW9 3DS, UK
}

\begin{abstract}
A phylogenetic analysis based on combined DNA sequences of the partial matK gene and the rpl16 intron showed that the rare alpine endemic Fritillaria tubiformis subsp. moggridgei (Liliaceae) and the more widespread $F$. tubiformis var. burnatii are exclusively related. A genetic study used plastid DNA markers, due to limits imposed by nuclear DNA fingerprinting in species with large genomes, to study variation within and between populations. Five length-variable homopolymer repeats (polyA and polyT) and four regions with one or two insertion/deletions (indels) of different lengths were identified. Of the total of 56 plastid haplotypes obtained, 32 were fixed in the seven populations of subsp. moggridgei and the rest were variable in var. burnatii. The analysis of molecular variance (AMOVA) showed higher genetic variation among rather than within subsp. moggridgei populations. Indel mutations, on the other hand, were fundamental in distinguishing the two taxa.
\end{abstract}

Key words: endemism, genetic diversity, Ligurian Alps, population differentiation, species range 


\section{Introduction}

More than $11 \%$ of the world flora is endemic to the Alps, and $81 \%$ of the narrow endemics are restricted to the Maritime and Ligurian Alps in the Italian provinces of Cuneo, Imperia and Savona (Aeschimann et al. 2011). Owing to the overall richness of the flora and incredibly high number of endemic species, this portion of the mountains has long been recognised as one of the biodiversity hotspots of the Mediterranean basin (Médail \& Verlaque 1997, Casazza et al. 2005, 2008, Aeschimann et al. 2011).

The peculiar co-occurrence in this region of geological, edaphic and climatic discontinuities has largely contributed to the current high level of diversity (Minuto et al. 2006, Grassi et al. 2009, Szövényi et al. 2009). Geographical and climatic gradients acting as natural barriers among species and populations can eventually lead to the differentiation of new endemic taxa (Thompson et al. 2005, Egisdottir et al. 2009, Schwienbacher et al. 2010 and references therein). Peripheral or locally rare populations can develop at boundaries of a species range and, in the presence of atypical habitats, diverge from central populations both morphologically and genetically (Jones et al. 2001, Hardie \& Hutchings 2010).

Fritillaria tubiformis Grenier \& Godron (1855: 13) subsp. moggridgei (Boissier \& Reuter ex Planchon, 1873: 116) Rix in Heywood (1978: 356) (Liliaceae) provides a good example of a rare taxon sporadically distributed across the southwestern Alps at a few localities in Italian Piedmont and Liguria (Charpin \& Salanon, 1985). In contrast, Fritillaria tubiformis subsp. tubiformis with dark purple flowers is not present in Liguria but has a much more widespread range in the Central Alps, the Piedmont to Valle d'Aosta and provinces of Bergamo and Brescia (Conti et al. 2005). However, in a recent paper reporting typification of Fritillaria tubiformis, Bartolucci and Peruzzi (2012) questioned the above-mentioned distribution and stated that the species has long been confused and often fully synonymized by Italian botanists with F. meleagris Linnaeus (1753: 304) subsp. burnatii (Planchon, 1873: 115) Rix in Heywood (1978: 356) (= F. delphinensis Grenier \& 
Godron (1855: 180) var. burnatii Planch.). In this regard, a biosystematic study is in progress aimed at clarifying the systematic status and distribution of the two taxa; however, irrespective of its closeness to $F$. meleagris or F. tubiformis, all Italian populations with dark purple flowers have been referred to F. tubiformis var. burnatii (Planch.) Rouy (1910: 403) (L. Peruzzi, Pisa, pers. comm.).

Understanding the details of population biology of endemics of this part of the Alps is a prerequisite for their conservation and predicting the impact of the global change on these rare species. Small, isolated populations often have low genetic variability and in changing environments are more prone to genetic erosion than larger populations (Frankham 1995, Booy et al. 2000, Ouborg et al. 2006, Jones et al. 2011 and references therein). Peripheral and small populations, nevertheless, may maintain a high degree of local differentiation as a consequence of scattered or geographically oriented distributions as documented in some rare plants (Booy et al. 2000, Egisdottir et al. 2009, Jones et al. 2011). Marginal populations indeed may contain unique genetic variation and be of particular value for conservation of a species.

Here, we have measured genetic variability of $F$. tubiformis subsp. moggridgei, including all seven presently known Italian populations. Genome size can limit the range of molecular markers available for nuclear DNA fingerprinting because these techniques perform suboptimally, and levels of polymorphism identified are typically an underestimate in taxa with large genomes (Fay et al. 2005). For example, multilocus fingerprinting methods such as AFLP (amplified fragment length polymorphism) have proved to be an efficient way of detecting polymorphisms in endangered and highly fragmented populations (Kitner et al. 2012), but this approach was ineffective (Fay et al. $2009)$ in species with large genomes as found in Fritillaria Linnaeus (1753: 303) $(1 \mathrm{C}=87.3 \mathrm{pg}$ in F. japonica Miquel, 1867: 158; Ambrožová et al. 2011).

For characterization of population diversity and genetic structure in F. tubiformis subsp. moggridgei, we designed ten plastid DNA markers. As demonstrated by Fay et al. (2009) for 
British plants of Cypripedium calceolus Linnaeus (1753: 951), plastid microsatellites represent an effective alternative to nuclear DNA markers to reveal genetic variability in species with large nuclear genomes.

Investigations that take into consideration divergence of infraspecific variants can provide information about how speciation happens and which factors are most important to promote divergence (McGlaughlin \& Friar 2011). This analysis has therefore been implemented with four populations of $F$. tubiformis var. burnatii sampled in the Piedmont at the boundary of the range of F. tubiformis subsp. moggridgei.

Given the possibility as hypothesised by Bartolucci \& Peruzzi (2012) that var. burnatii could be closer to F. meleagris than to $F$. tubiformis, before proceeding with the plastid DNA fingerprinting we conducted a maximum parsimony analysis on a combined DNA sequence matrix of the plastid mat $K$ gene and rpl16 intron to evaluate placement of $F$. tubiformis subsp. moggridgei relative to $F$. tubiformis var. burnatii, F. meleagris sensu stricto and other Eurasian Fritillaria species, as sampled in Rønsted et al. (2005)

The main foci of this research were: i) an analysis of genetic diversity and differentiation among and within populations of $F$. tubiformis subsp. moggridgei and potential ii) gene flow between this species and neighbouring populations of $F$. tubiformis var. burnatii. We will refer to the former taxon as subsp. moggridgei and the latter as var. burnatii throughout the remainder of this paper. In addition, we hope that our results would provide guidance for future conservation programs of this rare microendemic.

\section{Materials and methods}

Plant material

The plant material used in this study was collected from 11 populations of $F$. tubiformis s.l. distributed across the Maritime and Ligurian Alps. Italian populations of subsp. moggridgei are known to be distributed along the southernmost boundaries of the species range and were all 
sampled (Fig. 1, Table 1). Plant material was collected from plants in full bloom in May and June, 2009 and 2010. DNA was extracted from $40 \mathrm{mg}$ silica gel-dried leaf tissues using the E.Z.N.A. ${ }^{\circledR}$ SP Plant DNA Kit (Omega Bio-Tek, Norcross, GA) and purified on columns following the manufacturer's protocol.

Phylogenetic analysis

Sequences of plastid matK and rpll6 intron were obtained from subsp. moggridgei populations (MAR, CRA and FRO; Table 1) and var. burnatii (SER population; Table 1) and from one DNA sample of F. tubiformis deposited in the DNA Bank at the Royal Botanic Gardens, Kew (Table 2; http://apps.kew.org/dnabank/search). A further 26 sequences corresponding to most of the Eurasian Fritillaria species (F. tubiformis included) in Rønsted et al. (2005) were downloaded from GenBank (Table 2).

The $m a t K$ region was amplified using a combination of $-19 \mathrm{~F}$ and trnK-2R primers with the internal primers $390 \mathrm{~F}$ and $1326 \mathrm{R}$, which allowed for amplification and sequencing of the whole gene (approx. $1800 \mathrm{bp).} \mathrm{The} \mathrm{rpll6} \mathrm{intron} \mathrm{was} \mathrm{amplified} \mathrm{using} \mathrm{primers} \mathrm{158F} \mathrm{and} \mathrm{1661R} \mathrm{(Rønsted} \mathrm{et}$ al. 2005).

PCR amplifications were run in a Gene Amp 9700 PCR system (ABI, Applied Biosystems, Warrington, Cheshire, UK) using 5X Green GoTaq ${ }^{\circledR}$ Reaction Buffer (Promega BioScience, LLC. San Luis Obispo, CA, USA), EuroTaq (BioCat GmbH, Heildelberg, Germany) with $2.5 \mathrm{mM} \mathrm{MgCl} 2$ (ABGene, Epsom, Surrey, UK) and starting with 40-60 ng of genomic DNA in final reaction volumes of $20 \mu \mathrm{l}$. PCR profiles consisted of $15 \mathrm{~s}$ of initial denaturation at $90^{\circ} \mathrm{C}$, followed by 30 cycles of $94^{\circ} \mathrm{C}$ for $60 \mathrm{~s}, 50^{\circ} \mathrm{C}$ for $60 \mathrm{~s}$ and $65^{\circ} \mathrm{C}$ for $4 \mathrm{~min}$, and a final elongation step at $65^{\circ} \mathrm{C}$ for 5 min for the rpll6 gene and of $150 \mathrm{~s}$ initial denaturation at $94^{\circ} \mathrm{C}$, followed by 29 cycles of $94^{\circ} \mathrm{C}$ for $60 \mathrm{~s}, 52^{\circ} \mathrm{C}$ for $45 \mathrm{~s}$ and $72^{\circ} \mathrm{C}$ for $150 \mathrm{~s}$ with $8 \mathrm{~s}$ increments of the ramp at the completion of each cycle and a final elongation step at $72^{\circ} \mathrm{C}$ for $7 \mathrm{~min}$ for the $\operatorname{mat} K$ gene. PCR products were cleaned as detailed in the following section. 
Sequences were edited and assembled using Sequencher version 4.1 (Gene Codes, Ann Arbor, Michigan, USA). They were aligned manually with those retrieved from GenBank in PAUP* 4.0b4 for Macintosh (Swofford 2002). Matrices can be obtained from the first author (marco.mucciarelli@unito.it); DNA sequences produced for this study were deposited in GenBank (accession numbers KC409110, KC409111, KC409112, KC409113, KC409114, KC409115, KC409116, KC409117, KC409118). Cladistic analysis were conducted using PAUP* 4.0b4 (Swofford 2002). Sequences of Cardiocrinum giganteum (Wallich, 1824:21) Makino (1913:125) and Notholirion thomsonianum (Royle, 1839: 92) Stapf (1934: 95) were designated as outgroups in accordance with Rønsted et al. (2005). Phylogenetic analysis was conducted as described by Rønsted et al. (2005) using the heuristic search option. In brief, we performed 1000 replicates of random taxon addition using subtree-pruning-regrafting (SPR) branch swapping algorithm with 25 trees held at each step. Trees collectively found in these 1000 replicates were used as starting trees for a second search with no tree limit until all trees at this length were found. Robustness was assessed with bootstrap using 1000 replicates of simple addition and TBR swapping. Here we report only the strict consensus tree of 451 shortest trees (Fig. 2).

Identification of length-variable loci

We searched for length-variable loci flanked by conserved regions in non-coding spacers and introns of plastid DNA of $F$. tubiformis using primers given in literature (Taberlet et al. 1991, Shaw et al. 2007, Ebert \& Peakall, 2009) and starting with three representative samples of subsp. moggridgei and one sample of var. burnatii. Ten out of 35 loci (Table 3) proved to be variable. PCR amplifications were run in a Gene Amp 9700 PCR system (ABI, Applied Biosystems, Warrington, Cheshire, UK) using ReddyMix PCR Mastermix with $2.5 \mathrm{mM} \mathrm{MgCl}$ (ABGene, Epsom, Surrey, UK) and starting with 20-40 ng of genomic DNA in final reaction volumes of $25 \mu$ l. PCR profiles consisted of 3 min of initial denaturation at $94^{\circ} \mathrm{C}$, followed by 28 cycles of $94^{\circ} \mathrm{C}$ for $60 \mathrm{~s}, 48^{\circ} \mathrm{C}$ for $60 \mathrm{~s}$ and $72^{\circ} \mathrm{C}$ for $60 \mathrm{~s}$, and a final elongation step at $72^{\circ} \mathrm{C}$ for $7 \mathrm{~min}$. PCR products were cleaned 
using QIAquick ${ }^{\mathrm{TM}}$ PCR purification columns (QIAGEN Ltd., Crawling, West Sussex, UK) following the manufacturer's protocols. Samples were sequenced on an ABI 3730 capillary DNA genetic analyser using ABI Big Dye ${ }^{\circledR}$ Terminator v3.1 chemistry, following the manufacturer's protocols. For purifying products, we used ethanol precipitation. Raw sequences were edited and assembled using Sequencher version 4.1. They were aligned manually in PAUP* 4.0b4 (Swofford 2002), and variable regions were identified. Primers to amplify the length-variable regions were designed in conserved flanking regions. For each region, one primer was labelled with a fluorescent dye to enable amplification products to be visualized using an ABI 3100 genetic analyser. Sizes (bp) were determined using ABI GeneScan 3.1 and Genotyper 2.0 using the internal size standard $\mathrm{ABI}$ GeneScan ${ }^{\mathrm{TM}}-500 \mathrm{ROX}^{\mathrm{TM}}$ for all primer pairs. Fragments containing unique or rare indels were re-sequenced from new PCR products to test for reproducibility and exclude possible Taq-induced artefacts. Ten variable sites were scored for all individuals. A matrix was prepared, using different numbers for alleles of different lengths for each microsatellite and 1 vs. 2 for the simple indels and repeats (Table 4). If two different indel events occurred at the same position in different samples, as for the $p s b D$-trnT spacer (single indels of different lengths), alleles were numbered (Table 4).

\section{Definition of haplotypes}

As defined by a combination of alleles for the 10 loci, 56 were identified. Each haplotype was defined by the exact number of repeats, which allows these to be analyzed according to the stepwise mutation model (SMM) (measuring genetic differentiation among populations according to variance in allele size; Slatkin 1995). A table with haplotype definitions and frequencies is available upon request from the first author.

Statistical analysis

Haplotype frequencies in the sampled populations were estimated using ARLEQUIN software (Excoffier et al. 2005; data not shown). Overall gene diversity of $F$. tubiformis s.l. was estimated 
for each microsatellite locus as the total $\left(A_{\text {tot }}\right)$ and average number of alleles per population $\left(A_{\text {pop }}\right)$, allelic richness $\left(r_{(21)}\right.$, i.e. expected number of alleles observed in $n$ genets of each population corrected for differences in sample size by rarefaction as in Kalinowski, 2004, with $n=21$, the smallest population minus one, and the overall $H_{\mathrm{t}}$, Nei 1987, average within-population, $H_{\mathrm{s}}$, Nei 1987 and average among populations gene diversity, $D_{\text {st }}$; Table 5) using FSTAT (Goudet 2011).

Genetic diversity at the population level was estimated as the number of polymorphic loci $(N)$, proportion of polymorphic loci (polymorphic/usable loci) $(P)$, average number of alleles per locus $(A)$, average number of alleles over polymorphic loci (allele range) $\left(A_{\text {poly }}\right)$ and average (across loci) gene diversity (H; Edh et al. 2007; Table 6) using ARLEQUIN. $H$ is the probability that two randomly chosen sites are different, which is equivalent to gene diversity at the nucleotide level for DNA data assuming no recombination and selective neutrality (Excoffier et al. 2005). The proportion of private alleles $\left(f_{\text {private }}\right)$, (i.e. alleles unique to a particular population; Table 6) was calculated in CONTRIB (Rémy Petit, Petit@pierroton.inra.fr, INRA-Bordeaux). Total gene diversity $\left(H_{\mathrm{t}}\right)$, average gene diversity across loci $\left(H_{\mathrm{s}}\right)$ and proportion of private alleles $\left(\right.$ Allf $\left.f_{\text {private }}\right)$ were also calculated for all populations taken together (see below).

Genetic diversity was also estimated by calculating allelic richness $\left(r_{(21)}\right)$ per population using CONTRIB (Table 6). Although there were no differences in sample size of $F$. tubiformis s.l. populations except one, allelic richness was corrected using the rarefaction method (Kalinowski 2004). To provide robust estimates, the sample size of the smallest population sample minus one (n = 21; Table 6) was used for rarefaction (Fay et al. 2009).

Garza-Williamson statistics ( $G$-W index; Garza \& Williamson 2001) as modified by Excoffier $e t$ al. (2005) were calculated with ARLEQUIN (Table 6) in to test whether populations have suffered bottlenecks. This parameter takes into account the number of alleles at a given locus in a population and allelic range (for microsatellite data this is the difference between maximum and minimum 
number of repeats at all loci). Finally, number of haplotypes distributed within the 11 populations of F. tubiformis s.l. and their absolute frequencies were estimated using ARLEQUIN.

For estimating population differentiation, genetic divergence $\left(G_{\mathrm{st}}\right)$ of Nei's statistics (Nei 1973) (relative differentiation in Pons \& Petit 1996) was also calculated in CONTRIB on unordered haplotypes (Table 6) and for the two subspecies also ( $G_{\text {st }}$; Table 7; Fay et al. 2009). Because standardized measurement of $G_{\text {st }}^{\prime}$ allows more appropriate measures of genetic differentiation than $G_{\mathrm{st}}\left(\right.$ or $\left.F_{\mathrm{st}}\right)$ (it is independent of number of samples and rate of mutation; Slatkin 1995, Ægisdóttir et al. 2009 and references therein), $G_{\text {st }}$ and $G^{\prime}{ }_{\text {st }}$ were also calculated locus by locus in FSTAT.

To evaluate differences in resolution of genetic diversity based on the two types of repeat motifs (i.e. indels appear to evolve more rapidly than mononucleotide repeats and have a different frequency in the plastid DNA; Graham et al. 2000; Shaw et al. 2007), Nei's estimators of diversity $\left(H_{\mathrm{s}}, H_{\mathrm{t}}, G_{\mathrm{st}}, G^{\prime}{ }_{\mathrm{st}}\right)$ were also calculated in FSTAT for the indels and the five mononucleotide repeats separately.

For each taxon, total number of haplotypes, percentage of exclusive haplotypes, average number of polymorphic loci $(N)$, average number of alleles per locus $(A)$, allelic range $(R)$, proportion of private alleles $\left(f_{\text {private }}\right)$, total $\left(H_{\mathrm{t}}\right)$ and average within-population gene diversity $(H s)(\mathrm{Nei} 1987)$ were calculated in CONTRIB (Table 7). Average gene diversity across loci $(H)$ and Garza-Williamson statistics ( $G$ - $W$ index) were calculated with ARLEQUIN (Table 7).

Genetic structure in subsp. moggridgei populations was studied by analysis of the overall molecular variance (AMOVA) estimated among and within populations with ARLEQUIN (Table 8; Excoffier et al. 1992). To differentiate the contribution to variation derived from indels and single mononucleotide substitutions, degree of population differentiation and relative fixation indices were estimated by two statistical methods. The $F_{\mathrm{ST}}$ statistic following Weir \& Cockerham (1984) allows estimates of genetic structure indices based on the number of alleles and their frequencies in haplotypes. The $R_{\mathrm{ST}}$ statistic (Slatkin 1995) takes into account differences between allelic sizes 
(sum of square size differences). Both $F_{\mathrm{ST}}$ and $R_{\mathrm{ST}}$ statistics with the corresponding fixation indices were therefore calculated on overall variance (Table 8) and each locus (Table 9).

The AMOVA analysis was also performed by creating a genetic structure with two groups of populations corresponding to the two taxa (Table 8 , lower part). To test significance of AMOVA covariance components and fixation indices with and without this genetic structure, a nonparametric permutational approach (Excoffier et al. 1992) was used by permuting haplotypes among populations among groups $\left(\mathrm{F}_{\mathrm{ST}}\right)$, haplotypes among populations within groups $\left(\mathrm{F}_{\mathrm{SC}}\right)$ and populations among groups $\left(\mathrm{F}_{\mathrm{CT}}\right)$ for a total of 10100 iterations. By implementing a hierarchical analysis of variance, total variance was partitioned into covariance components due to inter- and intrapopulation differences as reported (Table 8).

\section{Haplotype network}

Two median-joining (MJ) networks (Bandelt et al. 1999) containing all shortest least complex trees (MP trees) were constructed using NETWORK 4.6.0.0. (www.fluxus-engineering.com). This method arranges haplotypes into a network where number of mutations along branches is a measure of divergence between haplotypes. In addition, the software uses parsimony criteria to identify median vectors, i.e. consensus of mutually similar sequences of markers, possibly equivalent to unsampled/extinct haplotypes. In order to evaluate the contribution of the five indels alone, and by implementing the data matrix with the remaining hypervariable regions (loci 1, 2, 3, 5, 6), two MJ networks were obtained (Fig. 3A-B). To reduce complexity of the resulting MJ network, rapidly changing and less discriminating characters were down-weighted (Fig. 3B) according to criteria in the program guidelines. The MP option, which deletes all non-MP links from the network, was in effect. 
Multidimensional scaling analysis (MSD)

To clarify genetic differentiation of $F$. tubiformis s.l. populations, a multivariate analysis was carried out by subjecting population pairwise estimates of $F_{\mathrm{ST}}$ (Weir \& Cockerham 1984; Fig. 5) and $R_{\mathrm{ST}}$ (Slatkin 1995; data not shown; see comments in Results) to a multidimensional scaling (MDS) in two dimensions with PCO 1.0 (principal coordinate analysis; Iwata 2004). This method allows for an interpretation of population association in a spatial model and is preferable to PCA (principal component analysis) methods since differences between near groups of individuals are resolved better by MDS, especially when number of individuals is large.

\section{Results}

Analysis of $m a t K$ and $r p l 16$

The combined plastid matrix contained 31 taxa including F. tubiformis s.l. (Table 1, Fig. 1) and other Fritillaria species (Table 2). The strict consensus tree (Fig. 2) showed that Fritillaria species fell into a well-supported group (99 bootstrap percentage, BP). Fritillaria tubiformis s.l. samples fell in a single clade ( $81 \mathrm{BP})$ sister to the clade containing most species of subgenus Fritillaria sensu Rix (2001). The four Piedmont samples of var. burnatii (SER) and subsp. moggridgei (MAR. CRA, FRO) formed a further subclade (61 BP) sister to F. tubiformis. Fritillaria meleagris was positioned far from this clade (Fig. 2).

Identification of length-variable regions

A total of 264 individuals representing seven populations of subsp. moggridgei and four populations of var. burnatii (Table 1) from the southwestern Piedmont and Liguria (Fig. 1) were analysed for ten variable plastid DNA regions (Table 3). Five mononucleotide repeats (A or T

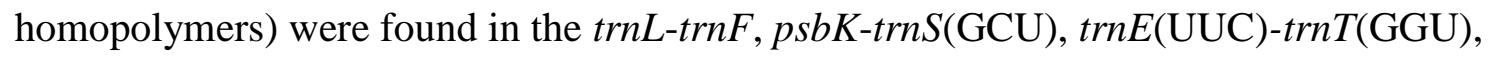
trnP(UGG)-petE/G and clpPexon1-psbB intergenic spacers of the LSC region of F. tubiformis s.l. These homopolymers were highly variable in the samples studied and ranged in size from 6 to 26 
bp (Table 4). Two species-specific simple indels (insertion/deletion) events and two simple plus one double species-specific indels of tandem repeats (repeats of an adjacent sequence) were observed. One indel consisting of a $5 \mathrm{bp}$ tandem repeat (ACTTT) was found at position 288 of the aligned matrix in the intron of the rpoClgene (rpoClexon2-rpoClexon1). Two single indels (tandem repeats of 30 and $17 \mathrm{bp}$ ) were found at position 316 of the aligned matrix in the $p \operatorname{sb}$-trnT(GGU) intergenic spacer of the LSC. An indel due to a tandem repeat of 9 bp (TTTTAGAAA) was detected at position 274 of the aligned matrix in the rpl33-rps 18 intergenic spacer (Table 4). Two indels of unique sequence at positions 228 and 388 of the aligned matrix, consisting of 7 (ATTCTTT) and 5 bp (CCGAA), respectively, were found in the petA-psbJ intergenic spacer. Among the six indels, four were deletion events (5, 9, 7 and $5 \mathrm{bp})$ shared between all members of $F$. tubiformis burnatii (Table 4; Fig. 3), and locus 7 ( $p s b D$-trnT) showed a 30-bp deletion shared between all the members of subsp. moggridgei (211 bp fragment length; Table 4; Fig. 3), except for a few members of the Vallone di Cravina (CRA) population, in which the deletion at locus 7 was 13 bp (228 bp fragment length; Table 4; Fig. 3). In all cases where sequences were redone from new PCR products, the same indels were found.

Haplotypes recovered and their distribution

All 10 length-variable regions were successfully scored; the final matrix contained information for 260 out of 264 individuals. All loci were highly variable, corresponding to a total number of 51 alleles (Table 4). Fifty-six haplotypes were obtained from the combined alleles for the ten scored regions (data not shown); nine haplotypes had at least one missing value and were therefore deleted from the data matrix. We found 24 haplotypes in var. burnatii and 32 in subsp. moggridgei, none of which was shared between the two species. Three haplotypes with the highest absolute and relative within-population frequencies, 45.5, 66.7 and 40.7\%, were found in populations GAL, MAR and SAC, respectively. Population CRA with nine was the richest population in haplotypes. Haplotypes in var. burnatii ranged from 5-8 per population, and only those belonging to PRA and DRO were 
population-exclusive. One haplotype from population PRA and one from ROS were the most frequent in var. burnatii (relative frequency 46.1 and 34.6\%, respectively).

Microsatellite diversity locus by locus

All loci were polymorphic, with the total number of alleles per locus ranging from $2-13$, with a total of 51 different alleles at the ten loci (Tables 4, 5). The average number of alleles per population $\left(A_{\mathrm{pop}}\right)$ ranged from 1.09-3.55 within a single locus, and almost all loci (four) containing indels were fixed within populations $\left(A_{\text {pop }}=1\right)$. Values for allelic richness $\left(\mathrm{r}_{(21)}\right)$ ranged from 2.00 10.34 , and overall gene diversity $\left(H_{\mathrm{t}}\right)$ varied considerably from $0.463-0.847$ for the most polymorphic locus ( $p s b K$-trnS; Table 5). According to locus, average within-population gene diversity $\left(H_{\mathrm{s}}\right)$ ranged from $0.031-0.444$ for mononucleotide repeats (average $0.179 \pm 0.042$ ) and was zero for indels. Estimates of gene diversity among populations $\left(D_{\text {st }}\right)$ defined by Nei (1987) as the absolute differentiation $\left(H_{\mathrm{t}}-H_{\mathrm{s}}\right)$ ranged from $0.329-0.506$, corresponding to $\mathrm{H}_{\mathrm{t}}$ at loci with indels.

Distribution of genetic diversity in F. tubiformis s.l. populations

Degree of population differentiation was high for all loci (Tables 6, 9). With a few exceptions, the 11 populations of $F$. tubiformis s.l. were variable in terms of number of polymorphic loci $(N)$ and proportion of polymorphic loci $(P)$. These were low in MAR (two loci; $P=20 \%$ ), SAM and CRA populations (three loci; $P=30-33 \%$ ) and high in ROS, FRO and SAC (five loci; $P=50 \%$; Table 6). Average number of alleles per locus $(A)$ varied even more, especially in subsp. moggridgei, ranging from 1.0 to 5.3 in MAR and SAM populations, respectively (Table 6). However, when considering only polymorphic loci $\left(A_{\text {poly }}\right)$, differences among populations decreased considerably (Table 6$)$. The proportion of private alleles $\left(f_{\text {private }}\right)$, unique to a single population, ranged from $8.3-15.4 \%$ in var. burnatii and from $6.7-10.0 \%$ in subsp. moggridgei. Populations SER and GAL had the highest proportions of private alleles in the two taxa; five populations had no 
unique alleles. Gene diversity $(H)$ varied considerably, ranging from $0.055-0.272$ in populations MAR and PLU (Table 6).

Total gene diversity across all populations was $H_{\mathrm{t}}=0.988 \pm 0.002$ and the average gene diversity across loci $H_{\mathrm{s}}=0.829$. Total percentage of private alleles $($ Allf private $)$ for $F$. tubiformis s.l. was $5.11 \%$. Allele richness was high for all populations except population MAR $\left(\mathrm{r}_{(21)}=1.88\right)$ and ranged from 7.14-11.15 in var. burnatii and from 5.82-13.18 in subsp. moggridgei (Table 6). G-W indexes varied between 0.817-1.000 (Table 6).

Genetic differentiation (Nei 1973) of F. tubiformis s.l. populations ranged from $G_{\mathrm{st}}=0.111 \mathrm{in}$ CRA population to 0.323 of MAR (Table 6), the most divergent population. When relative contribution to the genetic differentiation was evaluated per locus, indels showed the highest $G_{\text {st }}$ values $\left(G_{\mathrm{st}}=0.936-1.000\right.$ for locus 4 and loci 7-10). Estimated over all populations, $G_{\mathrm{st}}$ was 0.714 when calculated over all variable loci and $G_{\text {st }}=0.528$ when only mononucleotide repeats were considered and similarly with $G_{\text {st }}^{\prime}$ values $\left(G_{\text {st }}^{\prime}=0.733-0.552\right.$, respectively).

Distribution of genetic diversity in the two taxa

Among the 56 haplotypes, the proportion of subspecific-specific haplotypes was distributed as follows: 32 exclusive haplotypes belonged to subsp. moggridgei and 24 were exclusive to var. burnatii (Table 7). Genetic diversity was similar for the two subspecific taxa. There were six polymorphic loci in subsp. moggridgei and five in var. burnatii (as for other loci with indels, locus psbD-trnT was monomorphic in the four populations sampled for the latter taxon). The average number of alleles per locus was 2.9 for var. burnatii and 3.4 for subsp. moggridgei, probably as a consequence of the high allelic variation in the mononucleotide repeat loci in individuals of population SAM (Tables 4-7). The allelic range was $R=4.35$ for the species ( 4.35 is the average difference between the maximum and minimum number of repeats at all loci) and not statistically different in subsp. moggridgei $(R=4.5)$ or var. burnatii $(R=4.2)$. The proportion of private alleles was high in subsp. moggridgei $\left(f_{\text {private }}=4.5 \%\right.$ unique alleles $)$ and considerably higher in var. 
burnatii $\left(f_{\text {private }}=5.9 \%\right)$ for the contribution of populations SER and DRO (Table 7; see also Table 6). The remaining genetic indices were similar between the subspecies; values for total $\left(H_{\mathrm{t}}\right)$, across loci $(H)$ and within population $\left(H_{\mathrm{s}}\right)$ gene diversities were $0.998-0.988,0.325-0.329,0.805-0.870$ in subsp. moggridgei and var. burnatii, respectively (Table 7). $G-W$ indices were high for both subspecies (0.961-0.942), supporting estimates at the population level of Table 6. As expected from the similar values of $H_{\mathrm{t}}$ and $H_{\mathrm{s}}$, population differentiation ( $G_{\mathrm{st}}$ values) was low $(0.193-0.128$, subsp. moggridgei and var. burnatii, respectively).

Distribution of genetic variation

AMOVA showed that overall divergence among populations of subsp. moggridgei was high and that molecular variation was almost equally distributed among and within populations based on the infinite alleles and stepwise-mutation models: among populations $F_{\mathrm{ST}}=54.06 \%$ and $R_{\mathrm{ST}}=56.57 \%$; within populations $F_{\mathrm{ST}}=34.20 \%$ and $R_{\mathrm{ST}}=22.23 \%$ (Table 8$)$.

When the relative contribution of each locus to the total variation encountered in F. tubiformis s.l. was considered, we found that loci 4, 7, 8, 9 and 10 with only indels made the largest contribution to divergence among populations with no appreciable differences according to the statistical algorithm employed $\left(96.27-100 \%\right.$ and $99.04-100 \%$ for $F_{\mathrm{ST}}$ and $R_{\mathrm{ST}}$, respectively). In addition, all populations were fixed for these monomorphic loci $\left(F_{\mathrm{ST}}=0.963-1\right)($ Table 9$)$. On the other hand, microsatellite loci 1, 2, 3, 5 and 6 (and to some extent locus 7) made different contributions to the two components of total variation in accordance with the statistical algorithm employed. It is clear (Table 9) that microsatellite loci made the greatest contribution to the "among populations" component when evaluated according to the stepwise mutation model $\left(R_{\mathrm{st}}=\right.$ 61.89-94.57\%) and to the "within populations" component when in the infinite alleles model $\left(F_{\mathrm{ST}}=\right.$ 53.38-83.07\%; Table 9). Overall $F_{\mathrm{ST}}$ for the plastid loci in $F$. tubiformis s.l. was 0.66. 
Table 8 (lower part) also shows results for the distribution of genetic variation between the two subspecific taxa. The between-group component of total molecular variance was high $\left(F_{\mathrm{CT}}=0.625\right.$; $P<0.01$; Table 8$)$ and the proportion due to differences among population within subspecies $\left(F_{\mathrm{SC}}=\right.$ $0.510, P<0.0001 ;$ Table 8$)$ and due to differences within populations $\left(F_{\mathrm{ST}}=0.816, P<0.0001\right.$; Table 8) was similarly high and statistically significant. Similar results were obtained using the $R$ statistics $\left(F_{S T}=19.11 / 18.36 \%\right.$ and $R_{s t}=14.06 / 10.66 \%$; Table 8$)$. Existence of two main gene pools within $F$. tubiformis s.l. was therefore evident. Genetic variance among haplotypes of the two taxa represented the greatest portion of total variance and ranged from $62.53 \%$ with the infinite allele model $\left(F_{S T}\right)$ and $75.28 \%$ with the stepwise mutation model $\left(R_{s t}\right)$ (Table 8).

Haplotype network

Haplotype distribution and composition of $F$. tubiformis s.l. produced an MJ network (Fig. 3A) with no torso and only three nodes ( $\mathrm{Ha}, \mathrm{Hb} 1$ and $\mathrm{Hb} 2)$, which form two main clusters (A and $\mathrm{B}$ ) clearly partitioning the two taxa; clusters were separated from each other by five positions corresponding to the five indels at loci 4, 7, 8, 9, 10 (Fig. 3; Table 4). Haplotypes of var. burnatii clustered at the Ha node (37.8\% of the total number of individuals) and were characterized by a 241-bp fragment at locus 7 (region $p s b D$-trnT) and by four deletions (5-9 bp) at loci 4, 8, 9 and 10 (Table 4). Populations of subsp. moggridgei accounted for the remaining $62.2 \%$ of the total number of individuals, partitioned between haplotypes $\mathrm{Hb} 1$ and $\mathrm{Hb} 2$. Haplotype $\mathrm{Hb} 1$ is directly connected to the var. burnatii cluster and consists of the subsp. moggridgei individuals characterized by a 228bp fragment at locus 7 (Fig. 3A; Table 4). These are all individuals exclusive to the Cravina population (frequency 1.8\%) of the Valle Pesio (site \# 1 in Fig. 1). The second and larger cluster $\mathrm{Hb} 2$ (frequency 60.4\%) is composed of all remaining subsp. moggridgei individuals characterized by a 211-bp fragment at locus 7 (psbD-trnT; Fig. 3A).

By weighting phylogenetic distances within the network $(\varepsilon=10)$ a high-resolution full median MJ network of all ten microsatellites was obtained (Fig. 3B). It consisted of a torso connecting two 
main clusters with maximum parsimony, each one of closely related haplotypes (just one change between nodes). Cluster A comprised seven haplotypes for var. burnatii (total frequency 42.6\%), and cluster B was made up of 11 haplotypes of subsp. moggridgei (frequencies 57.4\%) (Fig. 3B).

The phylogenetic distance between the two clusters was due to six changes clearly separating the two taxa (Fig. 3B) and corresponding to the short indels at loci 4, 8, 9 and 10, the 13-bp indel at locus 7 (psbD-trnT) and the hypervariable locus 5 in the $\operatorname{trn} P-p e t E-G$ region. The median vector mv1 (Fig. 3B) is positioned between the two subspecific taxa in order to accommodate a hypothesised ancestral or missing sequence bearing a further $17 \mathrm{bp}$ indel in the $p s b-t r n T$ region (locus 7; Fig. 3B; Table 4). The haplotype distribution within the two taxa (cluster A and B) gave two complex networks. Two median vectors (mv3 and mv4) were positioned within cluster B in order to accommodate three peripheral haplotypes ( $\mathrm{Hp}, \mathrm{Hq}$ and $\mathrm{Hr}$ ) belonging to the southern populations of subsp. moggridgei from the Valle Tanaro (FRO and GAL; sites \# 3, 4, Fig. 1). On the other hand, the most common subsp. moggridgei haplotypes (SAC, CRA, MAR and SAM; site \# 9, 1, 5, 10, Fig. 1) occupied a central position in cluster B (Fig. 3B). Cluster A grouped all accessions of var. burnatii and showed a poorly resolved network with the four sampled populations largely intermixed.

Multidimensional scaling analysis (MDS)

According to multidimensional scaling, two main genetic groups were detected among the 11 populations of subsp. tubiformis s.l. (Fig. 4). The first two dimensions (PCO1 and PCO2) of the MDS plot accounted for $71.3 \%$ of total variance. The first axis (PCO1) corresponded to the greatest variation and broadly separated the two subspecific taxa in accordance with network results. This component is likely to represent the contribution of the five indel mutations to the overall differentiation between the two subspecies, and this was confirmed by populations of var. burnatii showing the same kind of indels here grouped closely (cluster B; Fig. 4). MSD was also useful for detecting populations possessing some intermediacy between the two genetic groups. This was 
reliable in the case of subsp. moggridgei populations, which were well resolved by the second axis (PCO2) accounting for $20.9 \%$ of variation. In accordance with NETWORK (Fig. 3, cluster B), the Val Tanaro populations (GAL and FRO) clustered together in the PCO plot, well separated from the remaining northernmost populations. Populations CRA SAC and SAM (Val Stura) grouped together irrespective of their geographic position (Fig. 4). Pian del Lupo, on the other hand, was separated from all other populations, in accordance with NETWORK results.

The MDS analysis stressed genetic differentiation between the taxa and supported a higher level of genetic complexity within the subsp. moggridgei populations. Similarly, when using $R_{\mathrm{ST}}$ estimates, which relies on the sum of square size differences, the PCO plot split all populations in two narrow clusters, with PCO1 accounting for almost all total variance (88.79\%; data not shown).

\section{Discussion}

Genetic variation in large genomes

As demonstrated by Fay et al. (2009) for British plants of Cypripedium calceolus, plastid DNA fingerprinting represent an alternative to nuclear DNA markers for revealing genetic variability in species with large nuclear genomes. Similarly, this problem has been addressed for Fritillaria, among which some of the largest genome sizes in the plant kingdom have been recorded (Ambrožová et al. 2011 and references therein). Li and colleagues (2011) found low genetic diversity in landraces of Fritillaria thunbergii Miquel (1867: 157), employing only nine intersimple sequence repeat (ISSR) bands out of 100 total markers scored. A total of 31 polymorphic (out of 54) RAPD markers were scored in the triploid F. camschatcensis Ker Gawler (1809: 1216) (Yamagishi et al. 2010) one of the smallest genomes in Fritillaria $(1 \mathrm{C}=38.4$ pg; Ambrožová et al. 2011). Our study has shown that plastid DNA fingerprinting is able to reveal genetic polymorphisms in natural alpine populations of $F$. tubiformis subsp. moggridgei, providing units of conservation. 
Indel-based DNA polymorphism and infraspecific diversification in Fritillaria tubiformis s.l.

Many studies so far have scored plastid regions and found substantial intraspecific indel polymorphisms, thus providing a useful tool for plant DNA fingerprinting (reviewed by Provan et al. 2001, Hamilton et al. 2003 and references therein, Fay et al. 2006, Micheneau et al. 2010, Schroeder et al. 2012). Inversions and insertions/deletions (indels) are major structural mutations of plastid DNA (reviewed by Kelchner 2000). Both may include phylogenetically relevant information, but indels are regarded as more reliable phylogenetic markers given the low levels of homoplasy of these microstructural characters (Graham et al. 2000). In contrast, several authors have acknowledged the possible highly homoplasious nature of small inversions, especially when employed at higher taxonomic level (Lehtonen et al. 2009). In this regard, large indels have been efficiently employed to infer phylogenetic relationships at the species and family level as demonstrated in Caryophyllaceae (Silene L.; Ingvarsson et al. 2003) and in Solanaceae (Capsicum annuиm L.; Jo et al. 2011). In F. tubiformis five regions of the plastid genome contained indels that were subspecies-specific (Figs. 3,4) and allowed for a clear assignment of all the populations with a total of 24 var. burnatii and 32 subsp. moggridgei exclusive haplotypes (Table 7; Fig. 3).

Through a combined matrix of matK and the rpll6 intron, we tested overall relatedness of the two subspecific groups of $F$. tubiformis populations in order to provide a basis for including both taxa in an analysis of genetic variation. The phylogenetic analysis was congruent with results obtained by Rønsted et al. (2005), positioning F. tubiformis s. l. with F. tenella Marschall von Bieberstein (1808: 269), F. lusitanica Wickström (1821: 352) and F. meleagris in the core clade of subgenus Fritillaria sensu Rix (2001). Our phylogenetic analysis identified a distinct F. tubiformis $s . l$. clade (B5) containing populations belonging to both flower morphotypes, taxonomically ascribed to var. burnatii and subsp. moggridgei. The former was clearly more related to the populations of subspecies moggridgei than to any other taxa in the analysis, including $F$. tubiformis sensu stricto employed as reference species (RBG DNA Bank samples and GenBank sequence 
accessions). This result was meaningful in testing the level of resolution of plastid markers in distinguishing among closely related populations of the two taxa. Analysis of molecular variance at each locus confirmed that plastid DNA indels were essential in indicating separation between the two taxa and that two genetic pools are recognizable in $F$. tubiformis based on the number of different alleles $\left(100 \%\right.$ percentage variation, $F_{\mathrm{ST}}=1.000$ and $F_{\mathrm{ST}}=0.963$ for the $p s b D$-trnT region; Table 9) and on differences at the polymorphic loci ( $100 \%$ percentage variation, $R_{\mathrm{ST}}=1.000$ and $R_{\mathrm{ST}}=0.990$ for the $p s b D$-trnT region; Table 9). When the MJ network resulting from the five indels was incorporated with variation in the $\operatorname{trn} P-p e t E / G$ spacer, which at the population level had the most informative of the mononucleotide repeats $\left(D_{\mathrm{ST}}=0.506, G_{\mathrm{ST}}^{\prime}=0.704\right.$, the highest values for all scored loci), it was clear that the two taxa were separated by at least six steps (Fig. 3B).

Although one must be careful in employing polymorphic haplotypes to make evolutionary inferences (Hamilton et al. 2003), the level of plastid DNA divergence recovered here was striking (99.8\% of the total gene diversity found in both taxa; Table 7), thus confirming utility of indels in measuring genetic variation between taxa. They differed in the proportion of private alleles and genetic divergence, which was greater in subsp. moggridgei $\left(G_{\mathrm{st}}=0.193\right.$ vs. 0.128 ; Table 7$)$. The latter found support in the PCO analysis (Fig. 4) based on allele frequencies, in which subsp. moggridgei populations were dispersed along the $\mathrm{PCO} 2$ component due to their greater genetic divergence (see, for example, populations MAR, CRA and PLU from Valle Pesio).

The $p s b D$-trnT spacer of the plastid LSC (large single copy) DNA has been found to be highly variable in Solanaceae (Daniell et al. 2006) and contains large indels (57-94 bp) in Minuartia L. (Caryophyllaceae; Shaw et al. 2007). The psbD-trnT spacer of F. tubiformis subsp. moggridgei revealed a 30-bp indel (211 bp fragment) in all but a few individuals, and these individuals possessed a larger fragment (228 bp) at the same position. The MJ network of all Fritillaria indels showed that individuals bearing the 228 bp fragment are ancestral to the whole subsp. moggridgei gene pool (Fig. 3A). Considering that this sub-population is located in the uppermost part of the 
Vallone di Cravina (CRA), we speculate that they may represent a founder population for all others in Valle Pesio.

Gene diversity and its distribution in populations of subsp. moggridgei and F. tubiformis s. $l$.

Average genetic diversity within populations of $F$. tubiformis s. $l$. was low $\left(H_{\mathrm{s}}=0.179\right.$; Table 5), especially when compared with values obtained by Fay et al. (2009) for Cypripedium calceolus $\left(H_{\mathrm{s}}\right.$ = 0.675), Egisdottír et al. (2009) in alpine Campanula thyrsoides L. $\left(H_{\mathrm{s}}=0.760\right)$ and Hodgins \& Barrett (2007) in Narcissus triandrus L. Otherwise, in Fritillaria $H_{\mathrm{s}}$ was comparable with the low values obtained by Edh et al. (2009) for nuclear microsatellites in the endemic Brassica cretica Lam. $\left(H_{\mathrm{s}}=0.211\right)$. Here, unlike nuclear DNA, no variation in plastid DNA was found, similar to the consistent indels in F. tubiformis.

When gene diversity was considered across all loci, however, it varied significantly between populations ranging from 0.055 in population Vallone del Marguareis (MAR) to 0.272 for population Pian del Lupo (PLU; Table 6). Low genetic diversity within endangered, rare or small populations is common and normally interpreted as a result of stochastic events like genetic drift, founder effects or population isolation (Edh et al. 2007). Furthermore, compared to widespread species, lower levels of gene diversity are normally expected within populations of endemic species regardless of their size (Edh et al. 2007 and references therein). However, the overall gene diversity of $F$. tubiformis was high at the species level $\left(H_{\mathrm{t}}=0.623\right.$, Table 5), falling in the range found in other species studied so far with plastid microsatellites $\left(H_{\mathrm{t}}=0.245-0.408 ; 0.907 ; 0.420-0.786\right.$ in Edh et al. 2009, Fay et al. 2009, and Honjo et al. 2009, respectively) and largely dependent on the overall gene diversity existing among populations $\left(D_{\mathrm{ST}}=0.445\right.$; Table 5$)$.

AMOVA supported these observations and, consistent with genetic indices, showed that greater genetic variation is to be expected "among" rather than "within" subsp. moggridgei populations (FST 54.06 vs. $45.94 \%$, Table 8 upper part). Percentage variation of the "within populations" component, however, ranged between $45.9-43.4 \%$, proving that despite a consistent degree of 
genetic isolation, gene flow still creates variability among individuals of subsp. moggridgei. When AMOVA was repeated on both taxa (Table 8, lower part), percentage variation was equally distributed "among" and "within" populations (FST 19.11 vs. $18.36 \%$; RST 14 vs. 10\%, Tab 8 lower part), but in this case most variation was due to genetic differences between the two taxa. With regard to the possible causes of the observed low gene diversity within subsp. moggridgei populations, we can exclude bottleneck effects. Most populations exhibited high numbers of polymorphic loci and alleles per locus (Table 6) and a high proportion of private alleles (on average $5.11 \%$ ) compared, for example, with the results of Fay et al. (2009) for C. calceolus. Allelic richness was particularly high, higher than those recorded by Andrianoelina et al. (2009) in the endangered tropical tree Dalbergia monticola Bosser \& Rabevohitra $\left(H_{\mathrm{cp}}=0.26-0.66\right)$ and Narcissus triandrus by Hodgins \& Barrett (2007). In addition, $G$ - $W$ values were close to 1 in all populations sampled (Table 6). This statistic is sensitive to population bottlenecks and is expected to be close to one in stationary populations (Garza \& Williamson 2011).

Genetic drift and population isolation along narrow alpine valleys is probably the cause of low gene diversity observed within most of subsp. moggridgei populations. Allelic richness is a gene diversity parameter suggested to be useful for identifying populations that deserve special management because of reduced diversity, i.e. population bottlenecks reduce allelic richness more quickly than heterozygosity (Kalinowski 2004). In this context, population MAR actually showed gene diversity indices notably lower $\left(A=1\right.$ and allelic richness $\left.r_{(21)}=1.88\right)$ than any other population. We feel, therefore, that this population should be regarded as a priority target in future conservation of $F$. moggridgei in Valle Pesio. In consideration of its lower elevation with respect to the other two populations in the same valley (PLU and CRA) population MAR is likely to have originated from a founder/s brought down during transhumance of cattle.

As argued by Ægisdottír et al. (2009) for C. thyrsoides, we believe that considerable genetic differentiation is to be expected in F. tubiformis considering that, except for occasional long- 
distance transport of seeds by grazing animals, this species has limited seed dispersal capacities. As observed in the literature, geological and climatic discontinuities typical of the Alps acting as natural barriers among species and populations (Ægisdottir et al. 2009, Schwienbacher et al. 2010 and references therein) may lead to fragmentation of a widespread ancestral taxon (Hughes \& Hollingsworth 2008, Xu et al. 2011, Takahashi et al. 2011). Limitation of seed dispersal, clonality through bulb dispersion and habitat fragmentation may have resulted in genetically and morphologically distinct populations that diverged from the more widespread species towards development of localized endemics. Fritillaria tubiformis subsp. moggridgei is one such endemic from the Ligurian Alps.

\section{Conclusions}

Based on plastid DNA variation and haplotype distribution, we can claim that subsp. moggridgei and Italian populations of var. burnatii clearly belong to different genetic pools. This finding is consistent with our phylogenetic analysis and with: i) the high proportion of species-specific private alleles that fixed plastid haplotypes within the two taxa (Table 7; Fig. 3), ii) similar levels of gene diversity, iii) the fact that, when a genetic structure is introduced in the analysis, most genetic variation among populations is due to differences between subspecies moggridgei and var. burnatii (AMOVA, Tables 8). Based on the inferred steps among plastid DNA haplotypes, the two taxa are separated by a minimum of six with no observed intermediate haplotypes (Fig. 3).

Based on all these results, we feel that subsp. moggridgei may merit species rank. Further studies aimed at clarifying the systematic status and actual distribution of this taxon are already in progress. Our study indicates the hypothesis of a long and independent history with little or restricted gene flow of local populations of $F$. moggridgei. Special attention, therefore, should be devoted to all these populations because they may contain specific genetic variation e.g. adaptive germination and dormancy traits (Carasso et al. 2011, 2012) of high value for maintenance of the species in a longterm evolutionary perspective. 


\section{Acknowledgements}

This work was almost entirely performed at the Jodrell Laboratory of the Royal Botanic Gardens, Kew, and on the mountains thanks to the aid of the staff of the Parco Naturale del Marguareis who supervised and supported field sampling. We also acknowledge financial support from the Word Wilde Style Project researcher mobility program sponsored by the Italian MIUR and by Fondazione CRT. We thank Lola Lledó for support in the laboratory as well as Robyn Cowan and Laura Stevens for advice and supervision during genotyping. The corresponding author is also grateful to Piero Belletti for the support during hiking.

\section{References}

Ægisdóttir, H.H., Kuss, P. \& Stöcklin, J. (2009) Isolated populations of a rare alpine plant show high genetic diversity and considerable population differentiation. Annals of Botany 104: 13131322.

Aeschimann, D., Rasolofo, N. \& Theurillat, J.P. (2011) Analyse de la flore des Alpes. 1: historique et biodiversité. Candollea 66: 27-55.

Ambrožová, K., Mandáková, T., Bureš, P., Neumann, P., Leitch, I.J., Koblizkova, A., Masac, J. \& Lysak, M.A. (2011) Diverse retrotransposon families and an AT-rich satellite DNA revealed in giant genomes of Fritillaria lilies. Annals of Botany 107: 255-268.

Andrianoelina, O., Favreau, B., Ramamonjisoa, L. \& Bouvet, J.M. (2009) Small effect of fragmentation on the genetic diversity of Dalbergia monticola, an endangered tree species of the eastern forest of Madagascar, detected by chloroplast and nuclear microsatellites. Annals of Botany 104: 1231-1242.

Bandelt, H. J., Forster, P. \& Roehl, A. (1999) Median-joining networks for inferring intraspecific phylogenies. Molecular Biology and Evolution 16: 37-48.

Bartolucci, F. \& Peruzzi, L. (2012) Typification of Fritillaria tubiformis Gren. \& Godr., Fritillaria delphinensis f. moggridgei Planch. and Fritillaria delphinensis var. burnatii Planch. (Liliaceae) from SW Europe. Candollea 67: 23-29.

Booy, G., Hendriks, R.J.J., Smulders, M.J.M., Van Groenendael, J.M. \& Vosman, B. (2000) Genetic diversity and the survival of populations. Plant Biology 2: 379-395. 
Carasso, V., Fusconi, A., Hay, F.R., Dho, S., Gallino, B. \& Mucciarelli, M. (2012) A threatened alpine species, Fritillaria tubiformis subsp. moggridgei: seed morphology and temperature regulation of embryo growth. Plant Biosystems 146: 74-83.

Carasso, V., Hay, R.F., Probert, J.R. \& Mucciarelli, M. (2011) Temperature control of seed germination in Fritillaria tubiformis subspecies moggridgei (Liliaceae) a rare endemic of the south-west Alps. Seed Science Research 21: 33-38.

Casazza, G., Barberis, G. \& Minuto, L. (2005) Ecological characteristics and rarity of endemic plants of the Italian Maritime Alps: the relationship between habitats and endemic/endangered taxa. Biological Conservation 123: 361-371.

Casazza, G., Zappa, E., Mariotti, M.G., Médail, F. \& Minuto, L. (2008) Ecological and historical factors affecting distribution pattern and richness of endemic plant species: the case of the Maritime and Ligurian Alps hotspot. Diversity and Distributions 14: 47-58.

Charpin, A. \& Salanon, R. (1985) Materiaux pour la flore des Alpes maritimes: catalogue de l'herbier d'Emile Burnat déposé au Conservatoire botanique de la ville de Genève. 1: Lycopodiaceae-Lentibulariaceae. Editions des Conservatoire et Jardin botaniques de la Ville de Genève, Genève, 258 pp.

Conti, F., Abbate, G., Alessandrin, A. \& Blasi, C. (2005) An annotated checklist of the Italian vascular flora. Palombi, Roma, 420 pp.

Daniell, H., Lee, S., Grevich, J., Saski, C., Quesada-Vargas, T., Guda, C., Tomkins, J. \& Jansen, R.K. (2006) Complete chloroplast genome sequences of Solanum bulbocastanum, Solanum lycopersicum and comparative analyses with other Solanaceae genomes. Theoretical and Applied Genetics 112: 1503-1518.

Ebert, D. \& Peakall, R. (2009) A new set of universal de novo sequencing primers for extensive coverage of noncoding chloroplast DNA: new opportunities for phylogenetic studies and cpSSR discovery. Molecular Ecology Resources 9: 777-1075.

Edh, K., Widén, B. \& Ceplitis, A. (2007) Nuclear and chloroplast microsatellites reveal extreme population differentiation and limited gene flow in the Aegean endemic Brassica cretica (Brassicaceae). Molecular Ecology 16: 4972-4983.

Excoffier, L., Laval, G. \& Schneider, S. (2005) Arlequin ver. 3.0: An integrated software package for population genetics data analysis. Evolutionary Bioinformatics Online 1: 47-50.

Excoffier, L., Smouse, P.E. \& Quattro, J.M. (1992) Analysis of molecular variance inferred from metric distances among DNA haplotypes: application to human mitochondrial DNA restriction data. Genetics 131: 479-491. 
Fay, M.F., Bone, R., Cook, P., Kahandawala, I., Greensmith, J., Harris, S., Pedersen, H.A.E., Ingrouille, M.J. \& Lexer, C. (2009) Genetic diversity in Cypripedium calceolus (Orchidaceae) with a focus on north-western Europe, as revealed by plastid DNA length polymorphisms. Annals of Botany 104: 517-525.

Fay, M.F., Chase, M.W., Rønsted, N., Devey, D.S., Pillon, Y., Pires, J.C., Petersen, G., Seberg, O. \& Davis, J. (2006) Phylogenetics of Liliales: summarized evidence from combined analyses of five plastid and one mitochondrial loci. Aliso 22: 559-565.

Fay, M.F., Cowan, R.S. \& Leitch, I.J. (2005) The effects of genome size on the quality and utility of AFLP fingerprints. Annals of Botany 95: 237-246.

Fischer ex J.E., Alexander (1829) Notice regarding the Salt Lake Inder, in Asiatic Russia.

Communicated by Lieutenant J. E. Alexander, 16th Lancers, K. L. S. M. R. A. S. Corres. Mem. S. A. E., \& c. Edinburgh New Philos. J. 8: 18-20.

Frankham, R. (1995) Conservation genetics. Annual Review of Genetics 29: 305-327.

Garza, J.C. \& Williamson, E.G. (2001) Detection of reduction in population size using data from microsatellite loci. Molecular Ecology 10: 305-318.

Goldstein, D.B., Ruiz Linares, A., Cavalli-Sforza, L.L. \& Feldman, M.W. (1995) Genetic absolute dating based on microsatellites and the origin of modern humans. Proceedings of the National Academy of Sciences of the United States of America 92: 6723-6727.

Goudet, J. (2011): FSTAT, a program to estimate and test gene diversities and fixation indices (version 2.9.3). Available from http://www.unil.ch/izea/softwares/fstat.htlm (accessed: 10 October 2009)

Graham, S.W., Reeves, P.A., Burns, A.C.E. \& Olmstead, R.G. (2000) Microstructural changes in noncoding chloroplast DNA: interpretation, evolution, and utility of indels and inversions in basal angiosperm phylogenetic inference. International Journal of Plant Sciences 161: S83S96.

Grassi, F., Minuto, L., Casazza, G., Labra, M. \& Sala, F. (2009) Haplotype richness in refugial areas: phylogeographical structure of Saxifraga callosa. Journal of Plant Research 122: 377387.

Grenier, J.C.M. \& Godron, D.A. (1855) Notices botaniques sur quelques plates des genres Fritillaria, Asphodelus et Melica. Mémoires de la Société d'Emulation du Département du Doubs 6: 12-15 pp.

Grenier, M. \& Godron, M. (1855) Flore de France ou description des plantes qui croissant naturellement en France et en Corse, tome troisième, premièr partie. Dodivers et $\mathrm{C}^{\mathrm{e}}$, Besançon, $779 \mathrm{pp}$. 
Hamilton, M.B., Braverman, J.M. \& Soria-Hernanz, D.F. (2003) Patterns and relative rates of nucleotide and insertion/deletion evolution at six chloroplast intergenic regions in new world species of the Lecythidaceae. Molecular Biology and Evolution 20: 1710-1721.

Hardie, D.C. \& Hutchings, J.A. (2010) Evolutionary ecology at the extremes of species' ranges. Environmental Reviews 18: 1-20.

Heywood, V.H. (1978) Flora Europaea, notulae systematicae ad floram Europaeam spectantes. Botanical Journal of the Linnean Society 76: 297-384.

Hodgins, K.A. \& Barrett, S.C.H. (2007) Population structure and genetic diversity in tristylous Narcissus triandrus: insights from microsatellite and chloroplast DNA variation. Molecular Ecology 16: 317-332.

Honjo, M., Kitamoto, N., Ueno, S., Tsumura, Y., Washitani, I. \& Ohsawa, R. (2009) Management units of the endangered herb Primula sieboldii based on microsatellite variation among and within populations throughout Japan. Conservation Genetics 10: 257-267.

Hughes, M. \& Hollingsworth, P.M. (2008) Population genetic divergence corresponds with specieslevel biodiversity patterns in the large genus Begonia. Molecular Ecology 17: 2643-2651.

Ingvarsson, P.K., Ribstein, S. \& Taylor, D.R. (2003) Molecular evolution of insertions and deletion in the chloroplast genome of Silene. Molecular Biology and Evolution 20: 1737-1740.

Iwata, H. (2004) PCO ver.1.0. Available from URL: http://cse.naro.affrc.go.jp/iwatah/others/pco/index.html (accessed: 20 October 2010)

Jo, Y.D., Park, Y., Kim, J., Song, W., Hur, C.G., Lee, Y.H. \& Kang, B.C. (2011) Complete sequencing and comparative analyses of the pepper (Capsicum annuиm L.) plastome revealed high frequency of tandem repeats and large insertion/deletions on pepper plastome. Plant Cell Reports 30: 217-229.

Jones, B., Gliddon, C. \& Good, J.E.G. (2001) The conservation of variation in geographically peripheral populations: Lloydia serotina (Liliaceae) in Britain. Biological Conservation 101: $147-156$.

Kalinowski, S.T. (2004) Counting alleles with rarefaction: Private alleles and hierarchical sampling designs. Conservation Genetics 5: 539-543.

Kelchner, S.A. (2000) The evolution of non-coding chloroplast DNA and its application in plant systematics. Annals of the Missouri Botanical Garden 87: 482-498.

Ker Gawler, J.B. (1809) Fritillaria racemosa, $(\alpha)$ oriental fritillary. Curti’s Botanical Magazine or, Flower Garden Displayed 30: pl. 1216.

Kitner, M., Majeský, L., Gillová, L., Vymyslický, T. \& Nagler, M. (2012) Genetic structure of Artemisia pancicii populations inferred from AFLP and cpDNA data. Preslia 84: 97-120. 
Lehtonen, S., Myllys, L. \& Huttunen, S. (2009) Phylogenetic analysis of non-coding plastid DNA in the presence of short inversions. Phytotaxa 1: 3-20.

Li, S., Hu, K., Guo, J., Yang, X., Zhu, Y. \& Cheng, Z. (2011) Genetic diversity and relationship of Fritillaria thunbergii Miq. landraces and related taxa. Biochemical Systematics and Ecology 39: 725-731.

Linnaeus, C. (1753) Species plantarum. Salvius, Stockholm, 560 pp.

Makino, T. (1913) Observations on the flora of Japan. Botanical Magazine Tokyo 27: 124-127.

Marschall von Bieberstein, F.A. (1808) Flora Taurico-Caucasica exhibens stirpes phaenogamas, in Chersoneso Taurica et regionibus caucasicis sponte crescentes. Charkouiae, Typis Academicis, 478 pp.

McGlaughlin, M.E. \& Friar, E.A. (2011) Evolutionary diversification and geographical isolation in Dubautia laxa (Asteraceae), a widespread member of the Hawaiian silversword alliance. Annals of Botany 107: 357-370.

Médail, F. \& Verlaque, P. (1997) Ecological characteristics and rarity of endemic plants from southeast France and Corsica: implications for biodiversity conservation. Biological Conservation 80: 269-281.

Micheneau, C., Duffy, K.J., Smith, R.J., Stevens, L.J., Stout, J.C., Civeyrel, L., Cowan, R.S. \& Fay, M.F. (2010) Plastid microsatellites for the study of genetic variability in the widespread Cephalanthera longifolia, C. damasonium and C. rubra (Neottieae, Orchidaceae), and crossamplification in other Cephalanthera species. Botanical Journal of the Linnean Society 163: 181-193.

Minuto, L., Grassi, F. \& Casazza, G. (2006) Ecogeographic and genetic evaluation of endemic species in the Maritime Alps: the case of Moehringia lebrunii and M. sedoides (Caryophyllaceae). Plant Biosystems 140: 146-155.

Miquel, F.A.W. (1867) Fritillaria, in Prolusio florae Japonicae. Annales Musei Botanici LugdunoBatavi 3: 157-158.

Nei, M. (1973) Analysis of gene diversity in subdivided populations. Proceedings of the National Academy of Sciences of the United States of America 70: 3321-3323.

Nei, M. (1987) Molecular evolutionary genetics. Columbia University Press, New York, 512 pp.

Nei, M., Tajima, F. \& Tateno, Y. (1983) Accuracy of estimated phylogenetic trees from molecular data. 2. Gene-frequency data. Journal of Molecular Evolution 19: 153-170.

Ouborg N.J., Vergeer, P. \& Mix, C. (2006) The rough edges of the conservation genetics paradigm for plants. Journal of Ecology 94: 1233-1248. 
Planchon, J.E. (1873) Sur les espèces de fritillaries de France, a propos des icons et d'un manuscrit inédit de Pierre de Belleval. Bulletin de la Société Botanique de France 20: 96-124

Pons, O. \& Petit, R.J. (1996) Measuring and testing genetic differentiation with ordered versus unordered alleles. Genetics 144: 1237-1245.

Provan, J., Powell, W. \& Hollingsworth, P. (2001) Chloroplast microsatellites: new tools for studies in plant ecology and evolution. Trends in Ecology \& Evolution 16: 42-147.

Rix, M. (2001) Fritillaria: a revised classification, together with an updated list of species. Alpine Garden Society, Worcestershire, 14 pp.

Rønsted, N., Law, S., Thornton, H., Fay, M.F., Chase, M.W. (2005) Molecular phylogenetic evidence for the monophyly of Fritillaria and Lilium (Liliaceae; Liliales) and the infrageneric classification of Fritillaria. Molecular Phylogenetics and Evolution 35: 509-527.

Rouy, G. (1910) Flore de France ou description des plantes qui croissant spontanément en France, en Corse et en Alsace-Lorraine, tome douzième. Société de sciences naturelles de la Charente Infériore, Paris, 505 pp.

Royle, J.F. (1839) Illustrations of the botany and other branches of the natural history of the Himalayan Mountains and the flora of Cashmere, V. 2 plates. Allen, London, 97 pp.

Schrenk, A. G. von (1841) Enumeratio plantarum novarum a cl. Schrenk lectarum / [F.E.L. Fischer, C.A. Meyer]. Fischer, Petrópolis, 113 pp.

Schroeder, H., Hoeltken, A.M. \& Fladung, M. (2012) Differentiation of Populus species using chloroplast single nucleotide polymorphism (SNP) markers - essential for comprehensible and reliable poplar breeding. Plant Biology 14: 374-381.

Schwienbacher, E., Marcante, S. \& Erschbamer, B. (2010) Alpine species seed longevity in the soil in relation to seed size and shape - A 5-year burial experiment in the central Alps. Flora 205: $19-25$.

Shaw, J., Lickey, E.B., Schilling, E.E. \& Small, R.E. (2007) Comparison of whole chloroplast genome sequences to choose noncoding regions for phylogenetic studies in angiosperms: the tortoise and the hare III. American Journal of Botany 94: 275-288.

Slatkin, M. (1995) A measure of population subdivision based on microsatellite allele frequencies. Genetics 139: 457-462.

Stapf, O. (1934) Lilium, Notholirion and Fritillaria. Bulletin of Miscellaneous Information (Royal Gardens, Kew) 1934: 94-96 
Sweet, R. (1826) Sweet's hortus Britannicus: or a catalogue of plants cultivated in the gardens of Great Britain, arranged in natural orders. Ridgway, London, 524 pp.

Szövényi, P., Arroyo, K., Guggisberg, A. \& Conti, E. (2009) Effects of Pleistocene glaciations on the genetic structure of Saxifraga florulenta (Saxifragaceae), a rare endemic of the Maritime Alps. Taxon 58: 532-543.

Taberlet, P., Gielly, L., Pautou G. \& Bouvet, J. (1991) Universal primers for amplification of three non-coding regions of chloroplast DNA. Plant Molecular Biology 17: 1105-1109.

Takahashi, Y., Takahashi, H. \& Maki, M. (2011) Comparison of genetic variation and differentiation using microsatellite markers among three rare threatened and one widespread toad lily species of Tricyrtis section Flavae (Convallariaceae) in Japan. Plant Species Biology 26: $13-23$.

Thompson, J.D., Lavergne, S., Affre, L., Gaudel, M. \& Debussche, M. (2005) Ecological differentiation of Mediterranean endemic plants. Taxon 54: 967-976.

Wallich, N. (1824) Tentamen florae Nepalensis illustratae, fasc. I, tav. 12-13. The Asiatic Lithographic Press, Calcutta, 117 pp.

Weir, B.S. \& Cockerham, C.C. (1984) Estimating $F$-statistics for the analysis of population structure. Evolution 38: 1358-1370.

Wickström, J.E. (1821) Beskrifning af tvenne nya arter af växtslägtet Fritillaria, jemte anmärkningar om åtskilliga arter af samma slägte. Kungliga Vetenskaps Academiens Handlingar 1821: 350-359.

Xu, T.T., Chen, J.A., Zhu, L.L. \& Li, Z.H. (2011) Development of microsatellite loci for Aconitum gymnandrum (Ranunculaceae), a species endemic to the Qinghai-Tibetan plateau. American Journal of Botany 98: e7-e9.

Yamagishi, M., Nishioka, M. \& Kondo, T. (2010) Phenetic diversity in the Fritillaria camschatcensis population grown on the Sapporo campus of Hokkaido University. Landscape and Ecological Engineering 6: 75-79. 
TABLE 1. Populations studied for Fritillaria tubiformis s.l.

\begin{tabular}{|c|c|c|c|c|c|c|c|}
\hline Acronym & $\#$ & Subspecies & Locality $^{*}$ & Latitude $(\mathrm{N})$ & Longitude (E) & Elevation (m) & Sample size ${ }^{\S}$ \\
\hline CRA & 1 & F.t. moggridgei & Vallone di Cravina $(\mathrm{CN})$ & $44^{\circ} 14^{\prime}$ & $007^{\circ} 38^{\prime}$ & $1420-1540$ & 24 \\
\hline DRO & 2 & F.t. burnatii & Droneretto $(\mathrm{CN})$ & $44^{\circ} 31^{\prime}$ & $007^{\circ} 12^{\prime}$ & $1700-1800$ & 24 \\
\hline FRO & 3 & F.t. moggridgei & Monte Frontè (IM) & $44^{\circ} 03^{\prime}$ & $007^{\circ} 45^{\prime}$ & $1980-1890$ & 24 \\
\hline GAL & 4 & F.t. moggridgei & Monte Galero $(\mathrm{CN})$ & $44^{\circ} 09^{\prime}$ & $008^{\circ} 00^{\prime}$ & 1690 & 22 \\
\hline MAR & 5 & F.t. moggridgei & Vallone del Marguareis (CN) & $44^{\circ} 11^{\prime}$ & $007^{\circ} 40^{\prime}$ & 1430 & 24 \\
\hline PLU & 6 & F.t. moggridgei & Pian del Lupo $(\mathrm{CN})$ & $44^{\circ} 11^{\prime}$ & $007^{\circ} 41^{\prime}$ & 1990 & 23 \\
\hline PRA & 7 & F.t. burnatii & S. Michele di Prazzo (CN) & $44^{\circ} 31^{\prime}$ & $007^{\circ} 02^{\prime}$ & $1960-2020$ & 24 \\
\hline ROS & 8 & F.t. burnatii & Alpe Pian Rosso (CN) & $44^{\circ} 09^{\prime}$ & $007^{\circ} 46^{\prime}$ & $1800-1910$ & 24 \\
\hline SAC & 9 & F.t. moggridgei & Monte Saccarello (IM) & $44^{\circ} 04^{\prime}$ & $007^{\circ} 43^{\prime}$ & 1900 & 24 \\
\hline SAM & 10 & F.t. moggridgei & Sambuco $(\mathrm{CN})$ & $44^{\circ} 20^{\prime}$ & $007^{\circ} 05^{\prime}$ & 1432 & 24 \\
\hline SER & 11 & F.t. burnatii & Vallone di Serpentera $(\mathrm{CN})$ & $44^{\circ} 13^{\prime}$ & $007^{\circ} 41^{\prime}$ & $1890-2000$ & 23 \\
\hline
\end{tabular}

"The two-letter code after localities indicates the administrative province (CN = Cuneo, Piedmont; IM = Imperia, Liguria). Numbers (\#) correspond to the sampled sites of Fig.1. ${ }^{\S}$ Sample size refers to the number of individuals for which haplotype data were collected. 
TABLE 2. Details of the plant and GenBank accessions used in the phylogenetic study.

\begin{tabular}{|c|c|c|c|c|}
\hline & Taxa & Voucher information & $\operatorname{matK}$ & rpl16 \\
\hline \multicolumn{5}{|c|}{ Subgenus Fritillaria } \\
\hline 1 & F. caucasica Adam & Chase 3488 (K), Kew 1989-1112 & AY624432 & AY624378 \\
\hline 2 & F. alburyana $\mathrm{Rix}$ & Chase 3470 (K), Kew1994-3139 & AY624429 & AY624375 \\
\hline \multicolumn{5}{|c|}{ Section Fritillaria } \\
\hline 3 & F. aurea Schott & Chase 3487 (K), Kew 1973-21448 & AY624430 & AY624376 \\
\hline 4 & F. acmopetala Boissier & Chase $2565(\mathrm{~K})$, Kew 1959-59401 & AY624426 & AY624372 \\
\hline 5 & F. hermontis Fenzl subsp. amana Rix & Chase 2563 (K), Kew 1974-2043 & AY 624440 & AY624387 \\
\hline 6 & F. crassifolia Boissier \& Huet du Pavillon. subsp. kurdica (Boissier \& Noë) Rix & Chase 2559 (K), Kew1985-926 & AY 624432 & AY624378 \\
\hline 7 & F. michailowskyi Fomin & Chase 2583 (K), Kew1981-3060 & AY624434 & AY624380 \\
\hline 8 & F. minuta Boissier \& Noë & Chase 2562 (K), Kew1978-3492 & AY 624448 & AY624396 \\
\hline 9 & F. olivieri Baker & Chase 2569 (K), Kew1963-51207 & AY624449 & AY624397 \\
\hline 10 & F. reuteri Boissier & Chase $2568(\mathrm{~K})$, Kew1969-6106 & AY624456 & AY624404 \\
\hline 11 & F. tubiformis Grenier \& Godron & Chase $2558(\mathrm{~K})$, Kew & AY624459 & AY624408 \\
\hline 12 & F. tubiformis Grenier \& Godron & Chase $2558(\mathrm{~K})$, Kew & This paper & This paper \\
\hline 13 & F.t. burnatii & population SER; see Table 1 & This paper & This paper \\
\hline 14 & F. tubiformis Grenier \& Godron subsp. moggridgei (Boissier \& Reuter ex Planchon) Rix & population MAR; see Table 1 & This paper & This paper \\
\hline 15 & F. tubiformis Grenier \& Godron subsp. moggridgei (Boissier \& Reuter ex Planchon) Rix & population CRA; see Table 1 & This paper & This paper \\
\hline 16 & F. tubiformis Grenier \& Godron subsp. moggridgei (Boissier \& Reuter ex Planchon) Rix & population FRO; see Table 1. & This paper & This paper \\
\hline 17 & F. lusitanica Wickström & Chase 2603 (K), Kew1980-3020 & AY 624443 & AY624391 \\
\hline 18 & F. meleagris Linnaeus & Chase $2566(\mathrm{~K})$, Kew1990-3088 & AY 624445 & AY624393 \\
\hline 19 & F. tenella Marschall von Bieberstein. & Chase $2561(\mathrm{~K})$, Kew1955-12701 & AY624458 & AY624407 \\
\hline 20 & F. pallidiflora Schrenk & Chase 2567 (K), Kew1959-1103 & AY 624450 & AY624398 \\
\hline
\end{tabular}


TABLE 2. (continued)

\begin{tabular}{|c|c|c|c|c|}
\hline & Taxa & Voucher information & $\operatorname{matK}$ & rpl16 \\
\hline & bgenus Japonica Rix & & & \\
\hline \multirow[t]{2}{*}{21} & F. japonica Miquel var. koidzumiana (Ohwi) Hara \& Kanai & AY624442 & AY624389 & AY624442 \\
\hline & bgenus Rhinopetalum Fisch & & & \\
\hline 22 & F. gibbosa Boissier & Photo M. W. Chase & AY624438 & AY624385 \\
\hline \multirow[t]{2}{*}{23} & F. karelinii (Fischer ex. D. Don) Baker & Chase $3461(\mathrm{~K})$, Kew1994-218 & - & AY624390 \\
\hline & bgenus Petilium Ludwig & & & \\
\hline 24 & F. raddeana Regel & Chase 745 (K), Kew1973-54 & AY624454 & AY624402 \\
\hline 25 & F. imperialis Linneus & Chase $2557(\mathrm{~K})$, Kew1970-3943 & AY624441 & AY624388 \\
\hline \multirow[t]{2}{*}{26} & F. chitralensis B. Mathew & Chase $3472(\mathrm{~K})$, Kew1970-4109 & AY624433 & AY624379 \\
\hline & bgenus Karolkowia Rix & & & \\
\hline \multirow[t]{2}{*}{27} & F. serwerzowii Regel & Chase 743 (K), Kew1933-Hoog & AY624457 & AY624405 \\
\hline & Ibgenus Theresia Koch & & & \\
\hline \multirow[t]{2}{*}{28} & F. persica Linneus & Chase 3496 (K), Kew1923-41201 & AY624451 & AY624399 \\
\hline & bgenus Davidii Rix & & & \\
\hline \multirow[t]{2}{*}{29} & F. davidii Franchet & B. Mathew 2000. Bulblets. & AY624435 & AY624381 \\
\hline & utgroups & & & \\
\hline 30 & Notholirion thomsonianum (Royle) Stapf & Chase $448(\mathrm{~K})$, Kew 1974-025 & AB024393 & AY624424 \\
\hline 31 & Cardiocrinum giganteum (Wall.) Makino & Chase 3689 (K), Kew1988-4907 & AY624469 & AY624425 \\
\hline
\end{tabular}

Classification of Fritillaria according to Rix (2001). Sample numbers (\#) in first column. For other information on species and vouchers see Rønsted et al. (2005).

GenBank accession numbers as in http://www.ncbi.nlm.nih.gov. 
TABLE 3. Primer sequences used to amplify ten variable regions of plastid DNA in Fritillaria tubiformis s.l.

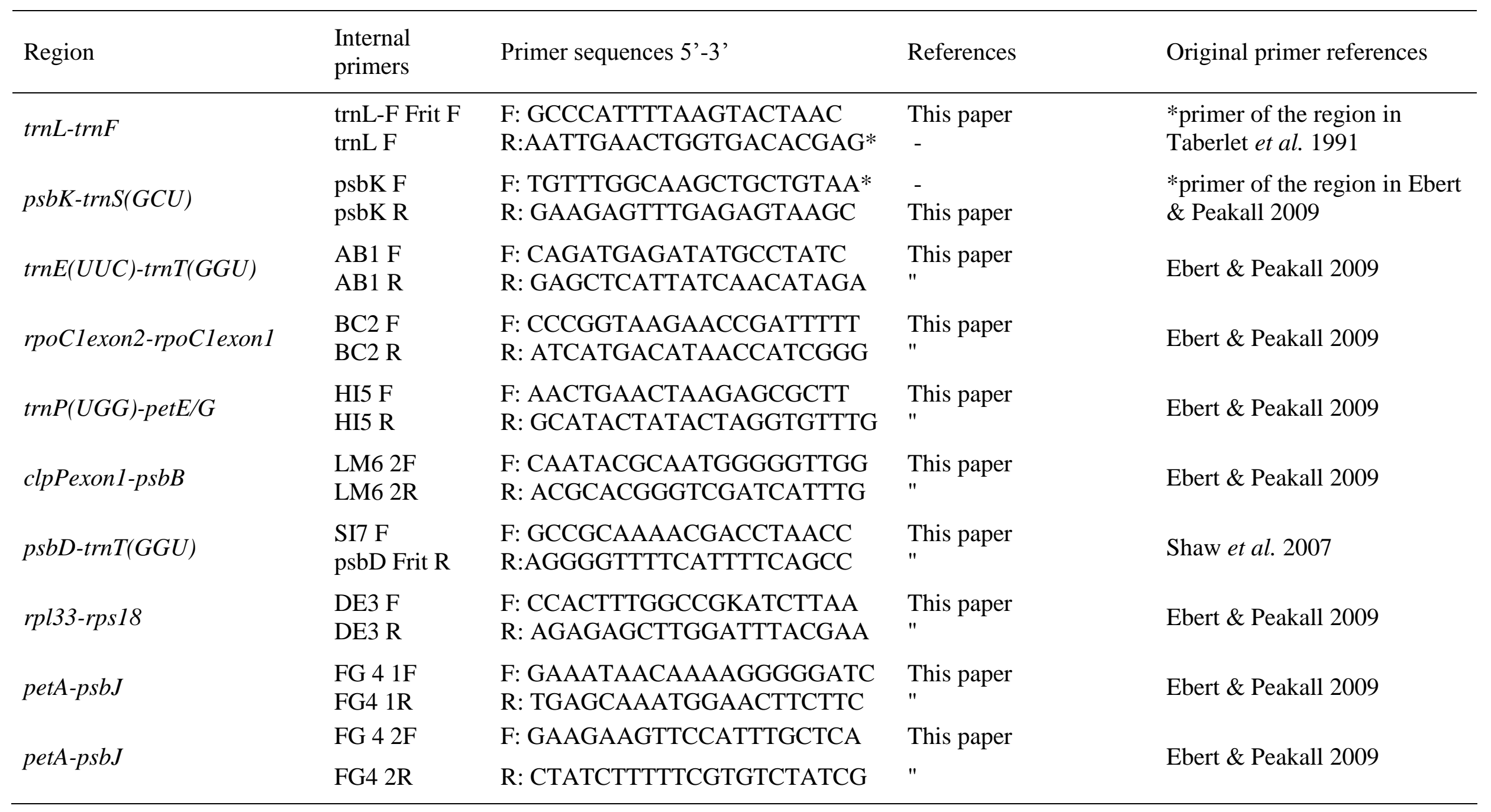


TABLE 4. Characterization of the five microsatellites and five indels of Fritillaria tubiformis s.l.

\begin{tabular}{|c|c|c|c|c|c|c|}
\hline Locus & Gene & Type of repeat motif & Repeat motif & Size range (bp) & Fragment length $^{*}(\mathrm{bp})$ & Alleles \\
\hline 1 & $\operatorname{trnL}-\operatorname{trn} F$ & polyT & $\mathrm{T}$ & $16-25$ & $235-245$ & $1,2,3,4,5,6,7,8,9,10$ \\
\hline 2 & $p s b K-t r n S$ & polyA & A & $13-26$ & $181-194$ & $1,2,3,4,5,6,7,8,9,10,11,12,13$ \\
\hline 3 & $\operatorname{trn} E-\operatorname{trn} T$ & polyT & $\mathrm{T}$ & $13-18$ & $153-158$ & $1,2,3,4,5,6$ \\
\hline 4 & rpoClex2-ex1 & repeat indel & $(\mathrm{ACTTT})_{2}$ & $5 / 10$ & $257 / 262$ & 1,2 \\
\hline 5 & trnP-petE/G & polyA & A & $6-12$ & $97-103$ & $1,2,3,4,5,6,7$ \\
\hline 6 & clpPexl-psbB & polyT & $\mathrm{T}$ & $8-11$ & $86-89$ & $1,2,3,4$ \\
\hline 7 & psbD-trnT & repeat indel & $\sim$ & $0 / 17 / 30$ & $211 / 228 / 241$ & $1,2,3$ \\
\hline 8 & rpl33-rps 18 & repeat indel & $(\text { TTTTAGAAA })_{2}$ & $9 / 18$ & $101 / 110$ & 1,2 \\
\hline 9 & petA-psbJ & indel I (from 5' end) & ATTCTTT & $0 / 7$ & $140 / 147$ & 1,2 \\
\hline 10 & petA-psbJ & indel II (from 5' end) & CCGAA & $0 / 5$ & $115 / 120$ & 1,2 \\
\hline
\end{tabular}

Name of the gene, type of repeat, motif and size in base pairs, total fragment length (bp) and alleles found are given for each locus. ${ }^{*}$ For indels and repeats the total length of the corresponding sequenced fragment is given; otherwise, it refers to the size range (bp) of the microsatellites. 
TABLE 5. Overall gene diversity analysed locus by locus.

\begin{tabular}{lllllll}
\hline Locus & $A_{\text {tot }}$ & $A_{\text {pop }}$ & $r_{(21)}$ & $H_{\mathrm{t}}$ & $H_{\mathrm{s}}$ & $D_{\text {st }}$ \\
\hline 1 & 10 & 2.82 & 7.796 & 0.838 & 0.395 & 0.444 \\
2 & 13 & 3.55 & 10.337 & 0.847 & 0.436 & 0.411 \\
3 & 6 & 2.27 & 5.938 & 0.773 & 0.444 & 0.329 \\
4 & 2 & 1.00 & 2.000 & 0.463 & 0.000 & 0.463 \\
5 & 7 & 2.18 & 6.124 & 0.741 & 0.234 & 0.506 \\
6 & 4 & 1.64 & 3.983 & 0.694 & 0.244 & 0.450 \\
7 & 3 & 1.09 & 2.575 & 0.486 & 0.031 & 0.455 \\
8 & 2 & 1.00 & 2.000 & 0.463 & 0.000 & 0.463 \\
9 & 2 & 1.00 & 2.000 & 0.463 & 0.000 & 0.463 \\
10 & 2 & 1.00 & 2.000 & 0.463 & 0.000 & 0.463 \\
Average \pm s.d. & - & - & - & $0.623(0.040)$ & $0.179(0.042)$ & $0.445(0.021)$ \\
\hline
\end{tabular}

* For locus definition see Table 2. $A_{\text {tot }}=$ total number of alleles; $A_{\text {pop }}=$ average number of alleles per population; $r_{(21)}=$ allelic richness; $H_{\mathrm{t}}=$ total gene diversity; $H_{\mathrm{s}}=$ average within population gene diversity; $D_{\mathrm{st}}=$ gene diversity among populations. 
TABLE 6. The overall gene diversity of $F$. tubiformis s.l. populations as estimated by a series of standard diversity indices.

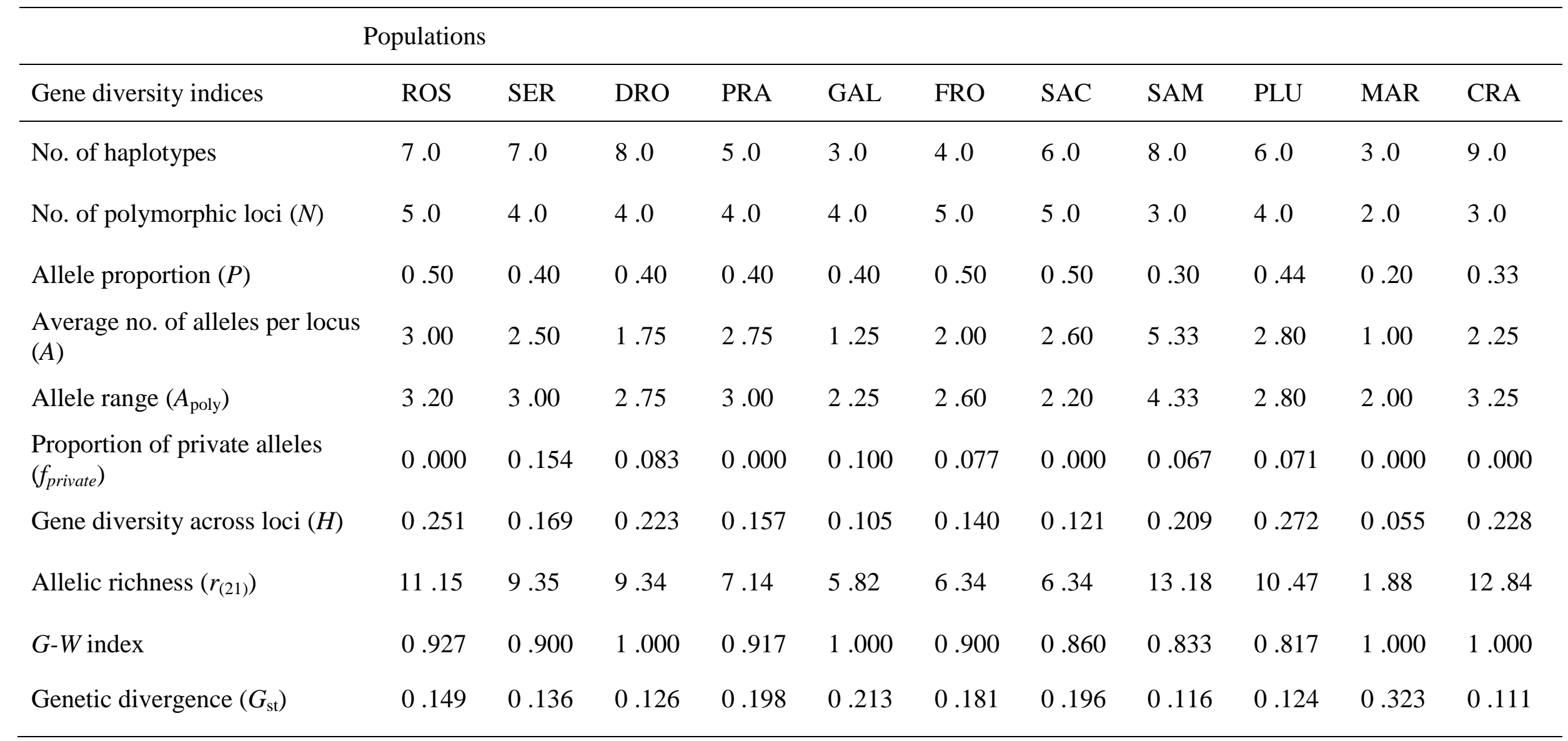

*For explanation of the populations acronyms see Table 1. $P$ is the proportion of polymorphic loci (polymorphic over usable loci); $A_{\text {poly }}$ is the average number of alleles over polymorphic loci; $f_{\text {private }}$ is the proportion of alleles unique to that particular population; $r_{(21)}$ is the allelic richness. For explanations of the remaining genetic parameters, see Materials and Methods. 
TABLE 7. Overall gene diversity within the two subspecific taxa of F. tubiformis s.l. as estimated by a series of standard diversity indices.

\begin{tabular}{lcc}
\hline Gene diversity indices & subsp. moggridgei & var. burnatii \\
\hline No. of haplotypes & 32.00 & 24.00 \\
Proportion of exclusive haplotypes $(\%)$ & 100.0 & 100.0 \\
No. of polymorphic loci $(N)$ & 6.000 & 5.000 \\
Average no. of alleles per locus $(A)$ & 3.400 & 2.900 \\
Allelic range $(R)$ & 4.500 & 4.200 \\
Proportion of private alleles $\left(f_{\text {private }}\right)$ & 0.045 & 0.059 \\
Gene diversity $\left(H_{\mathrm{t}}\right)$ & 0.998 & 0.998 \\
Gene diversity across loci $(H)$ & 0.325 & 0.329 \\
Average within population gene diversity $\left(H_{\mathrm{s}}\right)$ & 0.805 & 0.870 \\
$G$ - $W$ index & 0.961 & 0.942 \\
Genetic divergence $\left(G_{\mathrm{st}}\right)$ & 0.193 & 0.128
\end{tabular}

$* R$ is the difference between the maximum and minimum number of repeats at all loci; $f_{\text {private }}$ is the proportion of alleles unique to each subspecies. For explanations of the remaining genetic parameters, see Materials and Methods. 
TABLE 8. Distribution of plastid DNA variation among and within the seven populations of subsp. moggridgei (upper part) and when the analysis was implemented with the addition of four var. burnatii populations (lower part) as estimated by analysis of molecular variance (AMOVA).

\begin{tabular}{|c|c|c|c|c|c|c|c|c|c|}
\hline \multirow[b]{2}{*}{$\begin{array}{l}\text { Source of } \\
\text { variation }\end{array}$} & \multicolumn{2}{|c|}{ Sum of squares } & \multicolumn{2}{|c|}{ Variation components } & \multicolumn{3}{|c|}{ Variation $(\%)$} & \multicolumn{2}{|c|}{ Fixation indices } \\
\hline & $F_{\mathrm{ST}}$ & $R_{\mathrm{ST}}$ & $F_{\mathrm{ST}}$ & $R_{\mathrm{ST}}$ & d.f. & $F_{\mathrm{ST}}$ & $R_{\mathrm{ST}}$ & $F_{\mathrm{ST}}$ & $R_{\mathrm{ST}}$ \\
\hline $\begin{array}{l}\text { Among } \\
\text { populations }\end{array}$ & 137.44 & 676.20 & 0.938 & 4.631 & 6 & 54.06 & 56.57 & $F_{\mathrm{ST}}=0.541 * * *$ & $R_{\mathrm{ST}}=0.566^{* * *}$ \\
\hline $\begin{array}{l}\text { Within } \\
\text { populations }\end{array}$ & 125.95 & 561.73 & 0.797 & 3.555 & 158 & 45.94 & 43.43 & & \\
\hline Total & 263.39 & 1237.93 & 1.735 & 8.186 & 64 & 100.00 & 100.00 & & \\
\hline $\begin{array}{l}\text { Source of } \\
\text { variation }\end{array}$ & $F_{\mathrm{ST}}$ & $R_{\mathrm{ST}}$ & $F_{\mathrm{ST}}$ & $R_{\mathrm{ST}}$ & d.f. & $F_{\mathrm{ST}}$ & $R_{\mathrm{ST}}$ & $F_{\mathrm{ST}}$ & $R_{\mathrm{ST}}$ \\
\hline $\begin{array}{l}\text { Between } \\
\text { subspecies }\end{array}$ & 383.30 & 3545.10 & 2.992 & 28.328 & & 62.53 & 75.28 & $F_{\mathrm{CT}}=0.625^{* *}$ & $R_{\mathrm{CT}}=0.753 * *$ \\
\hline $\begin{array}{l}\text { Among } \\
\text { populations } \\
\text { within } \\
\text { subspecies }\end{array}$ & 202.31 & 1161.37 & 0.914 & 5.291 & & 19.11 & 14.06 & $F_{\mathrm{SC}}=0.510^{* * *}$ & $R_{\mathrm{SC}}=0.569 * * *$ \\
\hline $\begin{array}{l}\text { Within } \\
\text { populations }\end{array}$ & 218.75 & 998.60 & 0.879 & 4.010 & 7 & 18.36 & 10.66 & $F_{\mathrm{ST}}=0.816^{* * *}$ & $R_{\mathrm{ST}}=0.893 * * *$ \\
\hline Total & 804.36 & 5705.08 & 4.785 & 37.630 & $\rightarrow$ & 100.00 & 100.00 & & \\
\hline
\end{tabular}

$* * 0.001<P<0.01 ; * * * P<0.0001$ 
TABLE 9. Comparison of the distribution of plastid DNA variation among and within populations of $F$. tubiformis s.l. estimated with locus by locus analysis of molecular variance (AMOVA) employing the number of different alleles $\left(\mathrm{F}_{\mathrm{ST}}\right)$ and the sum of square size differences $\left(\mathrm{R}_{\mathrm{ST}}\right)$ as a distance method.

\begin{tabular}{|c|c|c|c|c|c|c|c|}
\hline $\begin{array}{l}\text { Source of variation } \\
\text { Locus }\end{array}$ & \multicolumn{2}{|c|}{$\begin{array}{l}\text { Among populations } \\
\text { Variation (\%) }\end{array}$} & \multicolumn{5}{|c|}{ Within populations } \\
\hline 1 & 19.32 & 61.89 & 80.68 & 38.11 & 0.193 & 0.619 & $<0.0001$ \\
\hline 2 & 18.98 & 72.43 & 81.02 & 27.57 & 0.190 & 0.724 & $<0.0001$ \\
\hline 4 & 100.00 & 100.00 & 0.00 & 0.00 & 1.000 & 1.000 & $<0.0001$ \\
\hline 5 & 46.62 & 94.57 & 53.38 & 5.43 & 0.466 & 0.946 & $<0.0001$ \\
\hline 6 & 44.53 & 78.48 & 55.47 & 21.52 & 0.445 & 0.785 & $<0.0001$ \\
\hline 7 & 96.27 & 99.04 & 3.73 & 3.73 & 0.963 & 0.990 & $<0.0001$ \\
\hline Average over loci & 65.98 & 77.80 & 34.02 & 22.20 & 0.660 & 0.778 & $<0.0001$ \\
\hline
\end{tabular}

For locus definition see Table 4. * The significance threshold was determined by 10100 permutations. 
Figure legends.

FIGURE 1. Map of the Italian populations of F. tubiformis s.l. Populations belonging to var. burnatii are labelled with a star symbol and those belonging to subsp. moggridgei with a solid circle. Most of the sampled populations are located at the boundary between Piedmont $(\mathrm{P})$ and Liguria (L) (Italy). Insets show, top left, sampling sites numbered as for populations (see Table 1) and, top right, the position of the sampled area within the Alps.

FIGURE 2. Strict consensus tree of more than 2600 most parsimonious trees from analysis of the combined plastid $m a t K$ and $r p l 16$ intron sequences. Tree length $=451$ steps, $\mathrm{CI}=0.89$ and $\mathrm{RI}=$ 0.85. Bootstrap percentages (> 50\%) are indicated above branches. Cardiocrinum giganteum and Notholirion thomsonianum are chosen as the outgroups. See also Table 2.

FIGURE 3. Median-joining (MJ) network for the combined plastid DNA data set of Fritillaria tubiformis s.l. A. MJ network based on indel repeats at locus 4, 7, 8, 9, 10. Haplotypes (Ha, Hb1 and $\mathrm{Hb} 2$ ) are indicated by the circles, the size of each circle being proportional to the observed frequency of each haplotype. B. MJ network for the combined plastid DNA data set of Fritillaria tubiformis s.l. based on all ten microsatellites. Median vectors are labelled mv1, mv2, mv3 and mv4. Number of changes required to explain transitions among haplotypes is indicated along the lines of the networks, except for connections that required only a single change. Information on the type and number of repeat motifs contributing to the network is provided for the two main clusters (A and B) corresponding to var. burnatii and subsp. moggridgei, respectively.

FIGURE 4. Principal coordinate analysis (PCO) of eleven populations of Fritillaria tubiformis s.l. analyzed for ten microsatellite loci. The first (PCO1) and the second (PCO2) axes explain 50.4\% and $20.9 \%$ of total variation, respectively. Acronyms correspond to populations (see Table 1). The two genetic groups corresponding to the two subspecific taxa are circled. 


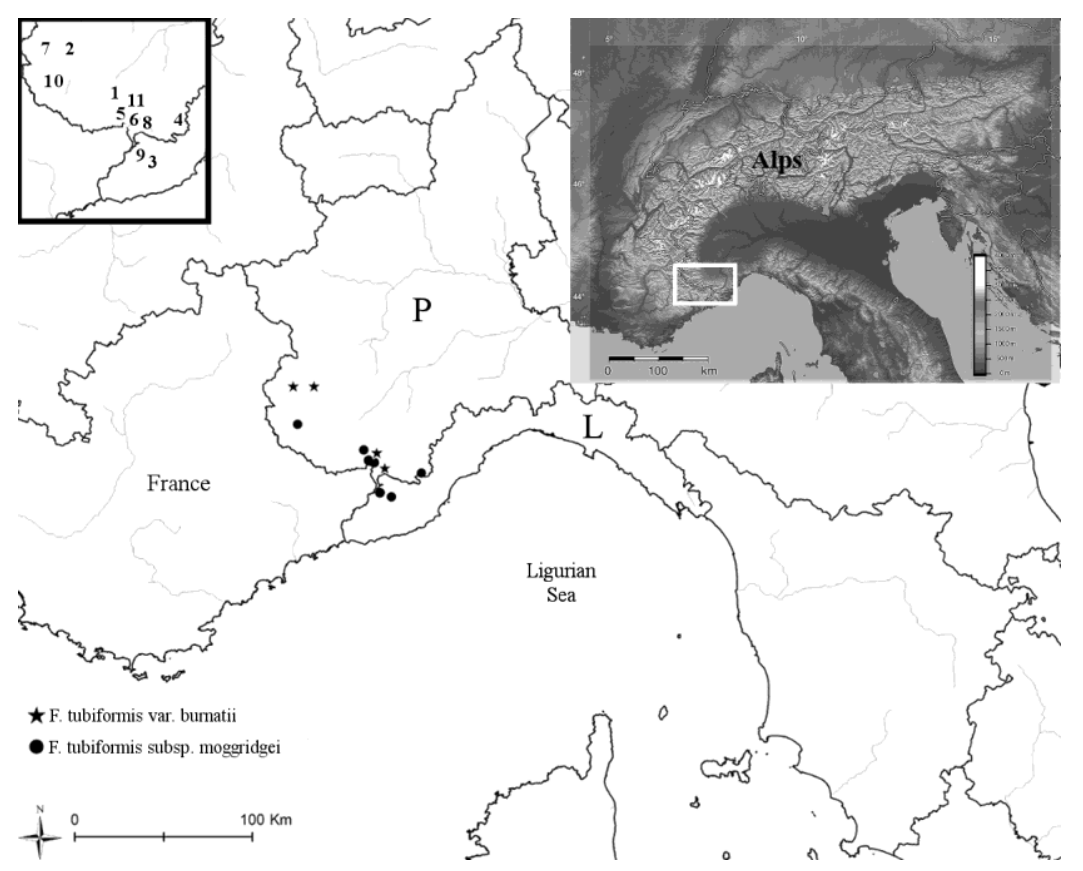

Fig. 1

A
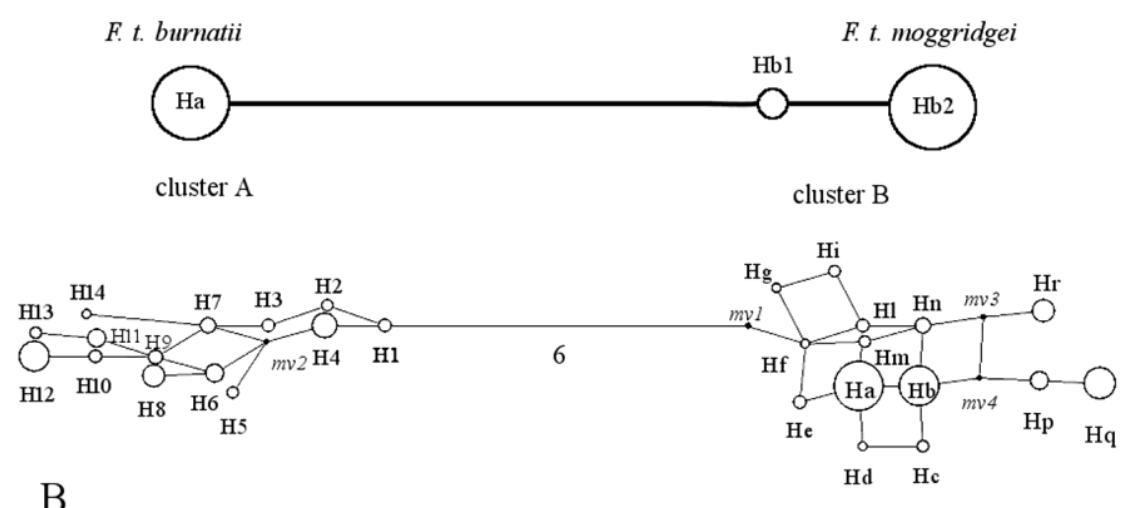

B

\begin{tabular}{|c|c|c|}
13 bp deletion at locus psbD-trnT & 17 bp deletion at locus psbD-trnT \\
\hline F. t. burnatii & four short deletions $(5-9 \mathrm{bp})$ at loci No.4,8,9,10 & F.t. moggridgei \\
\hline & 5 mutated positions & 1 mutated position
\end{tabular}

Fig. 2 


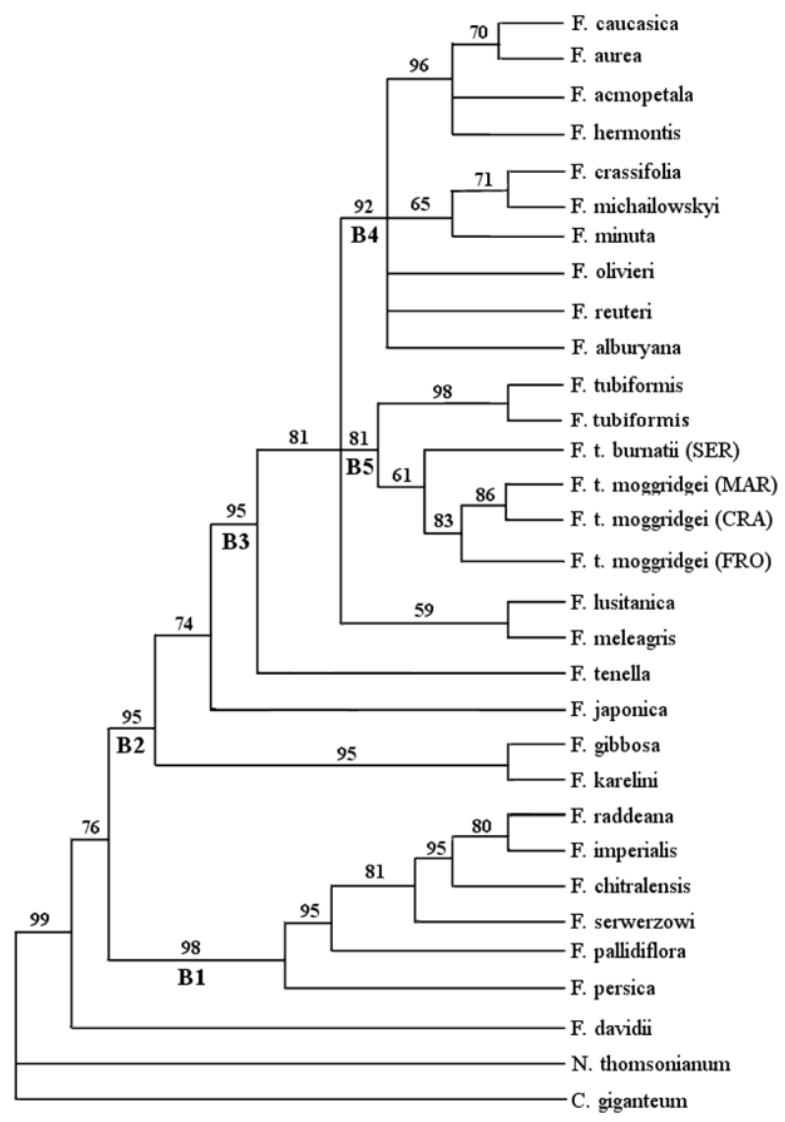

Fig. 3

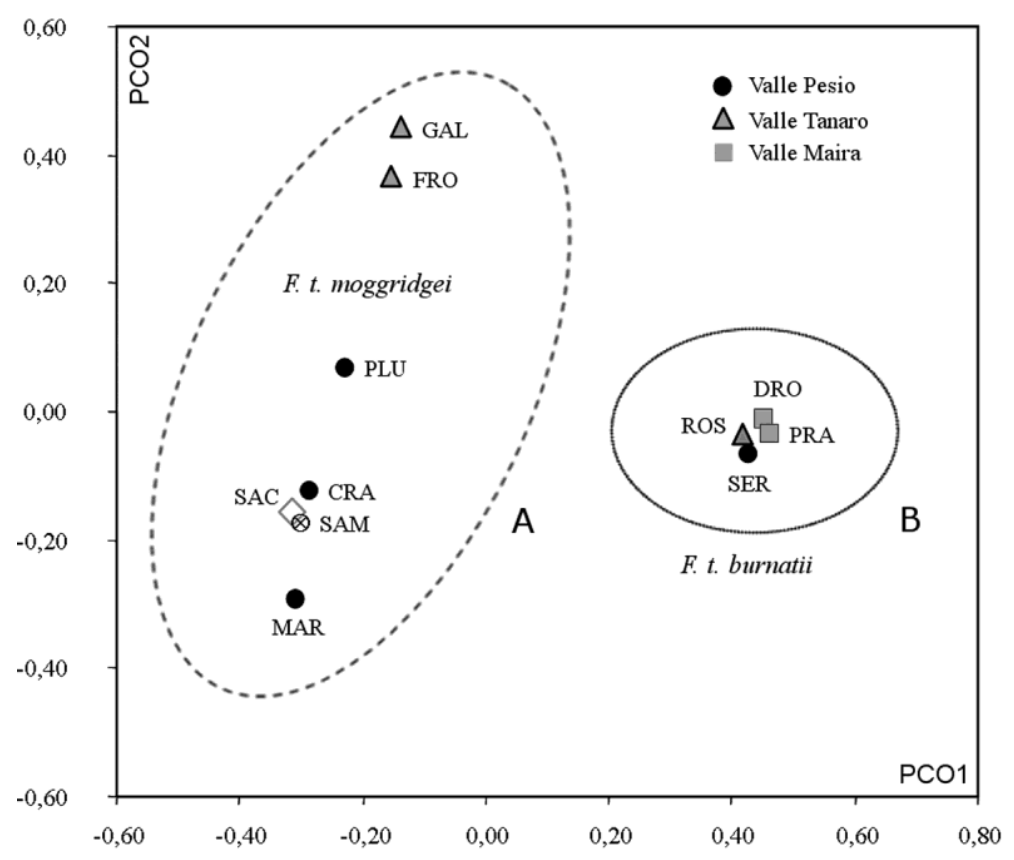

Fig. 4 